\title{
Role of The Purinergic Neuromodulation System in Epilepsy
}

\author{
Ângelo R. Tomé ${ }^{1,2}$, Henrique Silva ${ }^{1}$ and Rodrigo A. Cunha* ${ }^{* 1,3}$ \\ ${ }^{I}$ Center for Neurosciences of Coimbra, ${ }^{2}$ Department of Life Sciences, Faculty of Sciences and Technology, ${ }^{3}$ Institute of \\ Biochemistry, Faculty of Medicine, University of Coimbra, Portugal
}

\begin{abstract}
Adenosine has long been considered an endogenous anti-epileptic compound. This concept was based on the widespread distribution of adenosine $A_{1}$ receptors $\left(A_{1} R\right)$, which are mostly located in excitatory synapses; here, $A_{1} R$ inhibit glutamate release, decrease glutamatergic responsiveness and hyperpolarise neurons. However, the combined observation that synaptic $A_{1} R$ undergo desensitisation in chronic noxious situations whereas the activation of $A_{1} R$ still prevents seizure activity suggests that the $A_{1} R$ anti-epileptic action may involve non-synaptic mechanisms. Two alternative mechanisms can be considered to explain the ability of $A_{1} R$ to control seizure activity and resulting neurodegeneration: 1) the possible role of $\mathrm{A}_{1} \mathrm{R}$-mediated control of metabolism; 2) the $\mathrm{A}_{1} \mathrm{R}$-mediated preconditioning involving a coordinated control of neuron-glia communication. However, purinergic modulation of seizure activity is likely to involve other systems apart from $A_{1} R$. Thus, the blockade of adenosine $A_{2 A}$ receptors $\left(A_{2 A} R\right)$, which density increases in animal models of epilepsy, can attenuate seizure activity and prevent seizure-induced neurodegeneration. Furthermore, ATP, which is the main source of the endogenous adenosine activating $\mathrm{A}_{2 \mathrm{~A}} \mathrm{R}$, also act as a general danger signal and may also directly control seizure activity through $\mathrm{P}_{2}$ receptors $\left(\mathrm{P}_{2} \mathrm{R}\right)$. Therefore, the purinergic control of epilepsy may actually involve different parallel signalling arms, some beneficial and others deleterious, probably acting at different sites (in epileptic foci and in their neighbourhood) and at different times. It is likely that combined targeting of different purinergic receptors may be the most efficacious way to control seizure activity, its spreading and the resulting neurodegeneration.
\end{abstract}

Keywords: Adenosine, $\mathrm{A}_{1}$ receptor, $\mathrm{A}_{2} \mathrm{~A}$ receptor, ATP, $\mathrm{P}_{2}$ receptor, Epilepsy, Convulsion, Neurodegeneration, Neuroprotection, Synapse, Astrocyte, Neuron-Glia.

\section{SEIZURES, EPILEPSY - GENERAL FEATURES}

Seizures are identified by abnormal repetitive firing often with high coherency between different brain regions and are typically identified by characteristic perturbation of electroencephalographic activity, namely the presence of paroxysmal depolarisation shifts [1]. Seizures are the key signature of major syndromes collectively named 'epilepsy' that represent one of the heaviest burdens in medical care in the Western world [2]. Although it should be made clear that seizures can occur independently of behaviourally noticeable modifications (i.e. subclinical seizures), seizures have nevertheless prognostic significance in epilepsy-related outcome studies [3]. Seizures have traditionally been viewed as an imbalance between excitatory and inhibitory transmission in brain circuits, where hyper-excitation or hypo-inhibition would result in an abnormal repetitive firing of affected brain circuits [4]. This key idea has been the driving force for the design of the majority of anti-epileptic drugs, which aim to target either excessive firing or hyper-excitation or hypo-inhibition [5]. Thus, the initial group of anti-epileptic drugs was barbiturates, which bolster the inhibitory GABAergic system: they are effective to control seizures, but they also cause sedation [6]. This bolstering of inhibition was further aimed with the design of inhibitors of GABA transporters as candidate antiepileptic drugs $[7,8]$. Another family of anti-epileptic drugs, the family of carbamazepine and its derivatives, has a

*Address correspondence to this author at the Center for Neurosciences of Coimbra, Institute of Biochemistry, Faculty of Medicine, University of Coimbra, 3004-504 Coimbra, Portugal; Tel: +351 239820190; Fax: +351 239822776; E-mail: cunharod@gmail.com fundamentally different mechanism of action, since they act as inhibitors of over-activated sodium channels: they have minor effects on low frequency neuronal firing but restrain excessive recruitment of sodium channels [7,8]. Finally, recent efforts have been made to develop drugs to attenuate excessive glutamatergic activation $[7,8]$.

The fact that these drugs have successfully been used to manage epilepsy for several years clearly shows that the simple rationale of hyper-excitation/hypo-inhibition as a mechanism for seizure generation proved correct [5]. Nevertheless, clinical practice also makes it evident that these drugs are mostly effective when seizure activity is secondary to other conditions; in contrast, primary epilepsy syndromes, amongst which stems temporal lobe epilepsy, are notoriously less successfully managed by the current anti-epileptic drugs [9]. This should make us look at more detail into other modifications associated with seizures to attempt understanding if the imbalanced excitation/inhibition characteristic of seizures is not a consequence of other primary modifications. We will now briefly discuss two types of modifications that have been argued to be associated with seizures, namely the disruption of astrocytic networks and modifications of primary metabolism.

\section{1a. Seizures and Epilepsy - A Role for Astrocytes?}

There is now growing evidence indicating that astrocytes play a major role in the coordination of neuronal networks [10-13]. Astrocytes can sense a variety of active substances (neurotransmitters and neuromodulators), in fact, most of them [10-13]. Astrocytes can also release different neuroactive substances, tentatively named gliotransmitters [10-13], 
which can recruit other astrocytes or modify neuronal function. Actually, most of these gliotransmitters (but not all, e.g. D-serine) can also be considered neurotransmitters or neuromodulators, such as glutamate, ATP, NO or adenosine. Most importantly, astrocytes are connected forming a syncytium that covers large areas (up to $100 \mu \mathrm{m}^{2}$ [14]). This means that changes of activity in a particular point of a neuronal network can be transmitted over wide ranges to other points of the circuit through calcium waves in this astrocytic syncytium. This allows an effective coordination of neuronal networks in an integrative manner in view of the longer time course of astrocytic versus neuronal communication. Astrocytes are modified in conditions of epilepsy, both in terms of their enzymatic set-up, morphology or the extent of their syncytium [15-18], named astrocytic domain. However, it is currently unclear if episodic seizure activity is effectively accompanied by immediate reactive changes in astrocytes. Also, although provocative evidence has recently allowed proposing that epilepsy may be a primarily astrocytic rather than neuronal dysfunction [19], it has still not been demonstrated that a modification of astrocytic function can actually trigger seizures. Nevertheless, it is clear that astrocytes can potentially play a role in controlling seizure activity, making astrocytes a major player in the realm of epilepsy.

\section{1b. Seizures and Epilepsy - is Primary Metabolism Imbalance Involved?}

Primary metabolism is another key feature closely associated with seizures and epilepsy. In fact, maintaining neuronal activity represents a heavy metabolic burden to such an extent that it is calculated that circa $25 \%$ of the energy spent by the human body at rest is solely used to maintain the neuronal resting membrane potential [20]. The sudden enhancement of brain activity is only possible if it is sustained by an adequate metabolic support [21]. This enhancement of energetic recruitment during seizure activity is so evident that it constitutes a signature of brain imaging techniques aimed at locating epileptic foci [22]. There is clear evidence that epileptic conditions are accompanied by marked metabolic adaptation [23,24]. Also, there is (surprisingly) old evidence (first reported last century in the 20's, [25]) that fasting or ketogenic diets (which can be viewed as a controlled form of dietetic fasting [26]) can control seizure activity [27-29], being at least as effective as anti-epileptic drugs [30]. As was previously discussed for the case of astrocytic modifications, although it seems clear that modifications of primary metabolism are a key element controlling seizures, it still remains to be demonstrated if changes of primary metabolism can precipitate seizure activity or if instead these changes in primary metabolism represent a crucial adaptation to sustain a new imposed firing pattern.

\section{1c. Seizures and Epilepsy - Neurodegenerative Disor- ders?}

The presentation of these mechanistic features related to seizure activity has purposely been confused with the purported etiology of epilepsy. It was initially stated that seizures represented a key signature of 'epilepsy' [2], while it was also stated that seizure activity can be subclinical and be clearly distinguished from an epileptic condition [3]. This allows introducing a concept that emerges as evident in clinical practice, but has been repeatedly disputed in the lit- erature: the concept of seizure-beget-seizure [31]. In fact, the transition from normal brain functioning to an epileptic condition (named epileptogenesis) is accompanied by a series of modification, namely metabolic, morphological as well as in the set-up of different key proteins controlling excitability [15-18,32,33]. This clearly adds a further dimension to the relation between seizures and epilepsy: time, implying evolution and adaptation of the nervous system therein. The existence of a long period of adaptation between a precipitating factor and the occurrence of phenotypic modifications related to brain function is the seminal characteristic of neurodegenerative diseases. Furthermore, there is clear evidence of neuronal damage in different forms of epilepsy [34,35]. The extent might not be exuberant [36], but is similar to that found in other neurodegenerative diseases. Thus, epileptic syndromes should indeed be considered as neurodegenerative diseases. It is also important to consider neuronal damage as a key feature of 'epilepsies' that should be targeted by novel candidate anti-epileptic strategies.

\section{PHYSIOLOGICAL ROLES OF THE ADENOSINE NEUROMODULATION SYSTEM}

In view of this conception of seizure activity and epilepsy as a result of imbalanced excitation and inhibition in brain circuits as well as modified glial reactivity, modification of primary metabolism and neurodegeneration, the major goal of this review is to discuss the role and potential therapeutic interest of the purinergic system to manage seizure activity and convulsions. This will first require a short presentation of the purinergic system.

Purines are an often overlooked class of molecules. However, they integrate the constitution of the most fundamental systems regulating primary metabolism: thus, ATP, ADP and AMP are the key energetic determinants of metabolism and the energy charge is one of the major regulators of cell metabolism; the other major metabolic regulatory system is the redox system, which is mainly defined by the $\mathrm{NADH} / \mathrm{NAD}^{+}$ratio, both integrating a purine in their constitution; on the other hand, the hardware of the cell is actually defined by the ability to read DNA (also constituted by purines), which accessibility is controlled by histone methylation controlled by the ratio of $\mathrm{SAM} / \mathrm{SAH}$, again purinebased substances. Apart from these key intracellular regulatory functions, purines are also utilised as extracellular signalling molecules; thus, there is a controlled release of ATP and/or adenosine, both signalling through different types of receptors ( $\mathrm{P}_{2}$ and $\mathrm{P}_{1}$ receptors, respectively).

\section{2a. Adenosine $A_{1}$ Receptor Neuromodulation System}

Although the release of ATP and adenosine was first reported simultaneously [37], the role of adenosine as an extracellular signalling molecule was advanced first; this probably resulted from the finding that methylxanthines could prevent effects operated by adenosine [38], thus paving the way for a pharmacological characterization of adenosine $\left(\mathrm{P}_{1}\right)$ receptors. The active provision of different adenosine and methylxanthine analogues initiated by John Daly allowed proposing the existence of two classes of adenosine receptors, $A_{1}$ and $A_{2}$ receptors [39]. Apart from their different pharmacological profiles, these two classes of receptors were proposed to fulfil opposite signalling properties: $A_{1}$ receptors would display an inhibitory action, whereas $A_{2}$ 
receptors would be facilitatory receptors (based on their ability to modify cAMP levels, long though to be the main transducing system operated by adenosine receptors). Interestingly, in spite of the present evidence that the control of cAMP levels is only one of the different transducing systems operated by adenosine receptors, the notion that the actions of extracellular adenosine result from a balanced activation of inhibitory $A_{1}$ and facilitatory $A_{2}$ receptors still globally captures the functioning of the adenosine neuromodulation system in the central nervous system [40]. It is now established that there are 4 different adenosine receptors (all metabotropic receptors): $\mathrm{A}_{1}, \mathrm{~A}_{2 \mathrm{~A}}, \mathrm{~A}_{2 \mathrm{~B}}$ and $\mathrm{A}_{3}$ receptors [41]. However, in the brain, the role of extracellular adenosine has mostly been ascribed to the activation of inhibitory $A_{1}$ and facilitatory $\mathrm{A}_{2 \mathrm{~A}}$ receptors [40].

Adenosine $A_{1}$ receptors $\left(A_{1} R\right)$ are the most abundant adenosine receptor in the brain, displaying a widespread distribution [42]. They are most abundantly located in synapses [43,44], mainly in glutamatergic rather than GABAergic synapses $[45,46]$. Thus, $A_{1} R$ are powerful and effective modulators mainly of excitatory rather than inhibitory transmission (but see [47-50]), where they exert combined pre-, post- and non-synaptic effect to decrease synaptic transmission and excitability [40]. Presynaptic $A_{1} R$ are located in the active zone [44], where they control the influx of calcium through inhibition of $\mathrm{N}$ - and P-type voltage sensitive calcium channels [51] thus inhibiting the evoked release of glutamate [52]. Postsynaptic $\mathrm{A}_{1} \mathrm{R}$ decrease the responsiveness of glutamatergic synapses through a combined inhibition of N-type voltage sensitive calcium channels and of NMDA receptor function [53,54]. Neuronal non-synaptic $\mathrm{A}_{1} \mathrm{R}$ are particularly effective to control potassium channel conductances, thus hyperpolarising glutamatergic neurons [55]. The particular effect of $\mathrm{A}_{1} \mathrm{R}$ on AHPs (afterhyperpolarising potentials) [56] makes them potentially important targets to decrease integrative capacities of glutamatergic neurons, albeit this awaits experimental confirmation. The importance of this $\mathrm{A}_{1} \mathrm{R}$ neuromodulation system in glutamatergic synapses is best exemplified by two parallel observations: 1) there is an endogenous inhibitory tonus operated by the tonic activation of $\mathrm{A}_{1} \mathrm{R}$ by endogenous extracellular adenosine, indicating that this system is permanently active to restrain excitatory synaptic transmission [57]; 2) the supra-maximal activation of $\mathrm{A}_{1} \mathrm{R}$ can block excitatory synaptic transmission (see e.g. [58]). In fact, seminal work by Tom Dunwiddie showed that synaptic $\mathrm{A}_{1} \mathrm{R}$ are activated proportionally to on-going synaptic transmission [59]. Also, the pioneering work of Olivier Manzoni [60] paved the way to demonstrate the key role of $A_{1} R$ as final effectors of heterosynaptic depression in hippocampal circuits [61], which primarily involves the activation of the astrocytic syncytium triggering a long-distance ATP release yielding enhanced levels of extracellular adenosine in synapses distally located from that undergoing changes in activity [62]. But apart from these synaptic roles, $\mathrm{A}_{1} \mathrm{R}$ also play other roles in neuronal circuits, most of which are still poorly characterised. First, $\mathrm{A}_{1} \mathrm{R}$ have a marked impact on primary metabolism [63], which relevance for A1R-mediated effects still remains to be tested. $A_{1} R$ can also impose prolonged modifications of mitochondria function through control of $\mathrm{K}_{\mathrm{ATP}}$ activity, which is particularly relevant for the involvement of $A_{1} R$ in pre- conditioning [64]. Finally, although $\mathrm{A}_{1} \mathrm{R}$ are more abundantly located in neurons, they are also present at lower density in astrocytes [65], microglia [66] and oligodendrocytes [67], where their function is still ill-defined (reviewed in [68]).

\section{2b. Adenosine $A_{2 A}$ Receptor Neuromodulation System}

The role of adenosine $A_{2 A}$ receptors $\left(A_{2 A} R\right)$ is globally less explored than that of $A_{1} R$. This probably results from the traditional view that $\mathrm{A}_{2 \mathrm{~A}} \mathrm{R}$ were restricted to the striatum, where they have a particularly high density in enkephalinergic medium spiny neurons of the indirect pathway [69]. However, $\mathrm{A}_{2 \mathrm{~A}} \mathrm{R}$ are widespread throughout the brain [70-72], where they have a predominant presynaptic localization [73]. In accordance with their localization in the presynaptic active zone [73,74], some studies have defined the ability of $\mathrm{A}_{2 \mathrm{~A}} \mathrm{R}$ to enhance the evoked release of glutamate in different brain areas [74-77]. $\mathrm{A}_{2 \mathrm{~A}} \mathrm{R}$ are also located postsynaptically where they facilitate the activation of NMDA receptors [78] (but see [79]) and might also affect the resting membrane potential [80,81]. Interestingly, most electrophysiological studies were unable to demonstrate an ability of endogenous extracellular adenosine acting on $\mathrm{A}_{2 \mathrm{~A}} \mathrm{R}$ to control excitatory synaptic transmission under conditions of basal (low frequency) stimulation $[78,82,83]$. In contrast, a tonic activation of $\mathrm{A}_{2 \mathrm{~A}} \mathrm{R}$ seems required to assist the implementation of LTP $[78,84]$, suggesting that this $\mathrm{A}_{2 \mathrm{~A}} \mathrm{R}$ neuromodulation system is selectively involved in the control of synaptic plasticity [85]. $A_{2 A} R$ have also been proposed as fine-tuners of other neuromodulation systems [86], based on the requirement of their activation to observe synaptic effects of growth factors [87] or neuropeptides [88,89]. In parallel, $\mathrm{A}_{2 \mathrm{~A}} \mathrm{R}$ are also able to switch off presynaptic inhibitory systems, namely cannabinoid $\mathrm{CB}_{1}$ receptors [90] and $\mathrm{A}_{1} \mathrm{R}$ [77,91], either through a PKC-mediated desensitisation [91] or through formation of heteromers [77]. This makes $\mathrm{A}_{2 \mathrm{~A}} \mathrm{R}$ a hub, switching presynaptic modulation from inhibitory to facilitatory (see Fig. 1). Apart from these predominant synaptic effects, it has also been reported that $\mathrm{A}_{2 \mathrm{~A}} \mathrm{R}$ can impact on neuronal metabolism [92] but the functional relevance of this finding remains to be explored. Finally, $\mathrm{A}_{2 \mathrm{~A}} \mathrm{R}$ are also located in astrocytes and microglia cells $[68,93]$, where they control the uptake of glutamate [94] and the expression of cytokines [68,93].

\section{2c. Dynamics of the Extracellular Levels of Adenosine}

An aspect of uppermost importance that still awaits to be solved is the dynamics of the extracellular metabolism of adenosine. The traditional view argues that adenosine could be released through two main mechanisms: either released as such through non-concentrative nucleoside transporters or formed extracellularly upon release of ATP (either vesicular or non-vesicular, see [95-98]) and its catabolism through an ecto-nucleotidase pathway (see $[99,100]$ ). However, this view has numerous caveats. Certainly, solid work has allowed the cloning of different adenosine transporters, some equilibrative others concentrative [101]; also, the elegant work of Simon Robson and Herbert Zimmermann allowed a molecular characterization of the different families of ectonucleotidases, both ecto-nucleotides pyro-phosphatases (eNPP1-3) and ecto-nucleoside tri- and di-phosphatases (eNTPDase1-8) [102]. However, with respect to the predominant site of action of adenosine in the brain (i.e. in syn- 


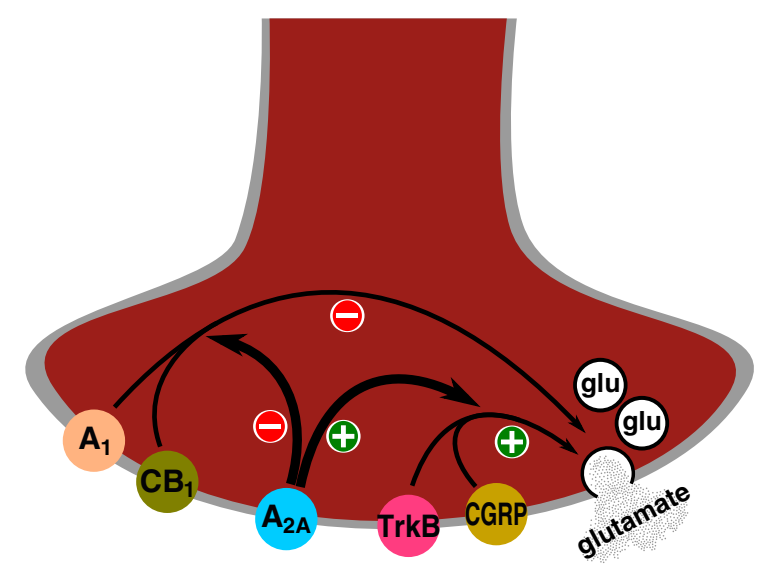

Fig. (1). Adenosine $A_{2 A}$ receptors act as a switch changing presynaptic modulation from inhibitory to facilitatory. Different studies have shown that the activation of $\mathrm{A}_{2 \mathrm{~A}}$ receptors can decrease the signalling ability of presynaptic inhibitory neuromodulation system in glutamatergic synapses, such as adenosine $A_{1}$ receptors or cannabinoid $\mathrm{CB}_{1}$ receptors. Conversely, the group of Alexandre Ribeiro in Lisbon has shown that the activation of $\mathrm{A}_{2 \mathrm{~A}}$ receptors seem to be required for the ability of presynaptic facilitatory neuromodulation systems, such as TrkB receptors (operated mainly by BDNF) or peptidergic receptors such as CGRP, to enhance the release of glutamate. Hence, as proposed initially by Paulo Correiade-Sá at the neuromuscular junction, $\mathrm{A}_{2 \mathrm{~A}}$ receptors seem to act as a selection device to change the sensitivity of glutamatergic terminals from mainly responsive to inhibitory signals (when $\mathrm{A}_{2 \mathrm{~A}}$ receptors are not activated) to mainly responsive to facilitatory signals (when $A_{2 A}$ receptors are activated). This ability of $A_{2 A}$ receptors to control both inhibitory and facilitatory systems has been proposed to be due either to the recruitment of intracellular transducing pathways (mainly protein kinases A or C) or to depend on the formation of heteromers between $A_{2 A}$ receptors and other receptors.

apses), there is simply no information about which nucleoside transporters (see [103]) or which ecto-nucleotidases might be present in different types of nerve terminals (see [104]). Also, only the few studies that used isolated nerve terminals [98,105-107], or fine electrophysiological techniques able to study individual synapses [78,108] or higher frequencies of stimulation [78,108-110], were able to document the importance of ATP-derived adenosine as a main source of endogenous extracellular adenosine. In contrast, several careful studies using different methodologies have largely failed to document that activity-dependent ATP release could be a major source of synaptic adenosine [111114]. This is probably due to the abnormally high catalytic efficiency of ecto-nucleotidases, which can convert ATP into adenosine within $50 \mathrm{~ms}$ [115] and are organised in a channelling manner with adenosine receptors [58]; thus, only genetic methods, for instance inactivating the vesicular release of ATP from astrocytes, have provided indirect support for the relevance of the ecto-nucleotidase pathway as a source of endogenous extracellular adenosine [62].

The understanding of the role of nucleoside transporters (AdoT) in defining the extracellular levels of adenosine is even more poorly understood. Whereas it is (strangely) accepted that adenosine can be released through nonconcentrative and bi-directional adenosine transporters, the evidence available instead suggests that AdoT are effectively dedicated to the removal of extracellular adenosine; in fact, inhibitors of AdoT bolster synaptic $A_{1} R$-mediated inhibition $[58,59,116,117]$, which can only be interpreted as an enhancement of the extracellular levels of adenosine. In fact, basic questions such as to know the relative contribution of neurons (namely synapses) and astrocytes for the clearance of adenosine are still unknown. Also, the possibility that there might be micro-domains defined by AdoT to confine the action of adenosine over $\mathrm{A}_{1} \mathrm{R}$ or $\mathrm{A}_{2 \mathrm{~A}} \mathrm{R}$ remains a tentative possibility that still awaits experimental confirmation. Great hope lies in the detailed characterization of a recent transgenic mouse line with a selective deletion of ENT1 [118]. Probably, mapping the cellular, synaptic and sub-synaptic relative localization of the different AdoT and ectonucleotidases would provide an initial informative view of the organization of these metabolic pathways where adenosine exerts its most evident effects, i.e. in synapses.

It is not only with respect to extracellular metabolism of adenosine that the picture is blurred; the characterisation of the intracellular bio-availability of adenosine is still poorly understood. Since de novo synthesis of purines is energetically costly, cells have developed different salvage pathways to re-use purine moieties. In the case of adenosine, it can undergo two major metabolic routes: either rephosphorylation into AMP through the action of adenosine kinase (ADK) or deamination through the action of adenosine deaminase (ADA) [119-122]. Initial studies suggested a simple picture: ADK was mainly a neuronal enzyme, whereas ADA was mainly an astrocytic enzyme [119-121]; furthermore, $A D K$ has lower $K_{M}$ and $V_{\max }$ values whereas ADA has higher $K_{M}$ and $V_{\max }$ values [119,122]; this suggested that extracellular adenosine should mainly be reutilised by neuronal ADK whereas astrocytic ADA would only come to play upon large variations of extracellular adenosine. Accordingly, functional studies indicate that ADK inhibitors have a more profound impact on $A_{1} R$ mediated synaptic transmission $[112,123,124]$ than ADA inhibitors $[116,124,125]$. This simple picture has been called into question by the elegant and consistent work of Detlev Boison: while it confirmed the primordial role of ADK in the metabolisation of adenosine [19], it showed that this enzyme was mostly astrocytic [19,126-128], in clear contrast to previous observation [119-121]. This favours the view that the termination of adenosine signalling might be a predominant astrocytic function (see Fig. 2), as proposed for other neuroactive substances such as glutamate [129]. However, it still remains to be understood what are the relative densities and activities of AdoT, ADK and ADA in nerve terminals, where adenosine receptors are enriched and where adenosine is mostly acting; this is not possible using brain sections or slices since nerve terminals only represent circa $1-2 \%$ of the total cortical volume in rodents [130]. Certainly, a careful characterization of the detailed synaptic action of adenosine under different stimulation conditions in different synapses in the transgenic mice with modified activity of ADA or of ADK (generated by Boison's group) might provide important insights into these questions.

\section{2d. Proposed Coordinated Role of $A_{1}$ and $A_{2 A}$ Receptors in Controlling Brain Circuits}

Obviously, the aim of a reader less familiarised with the adenosine neuromodulation system will be to find a simple 

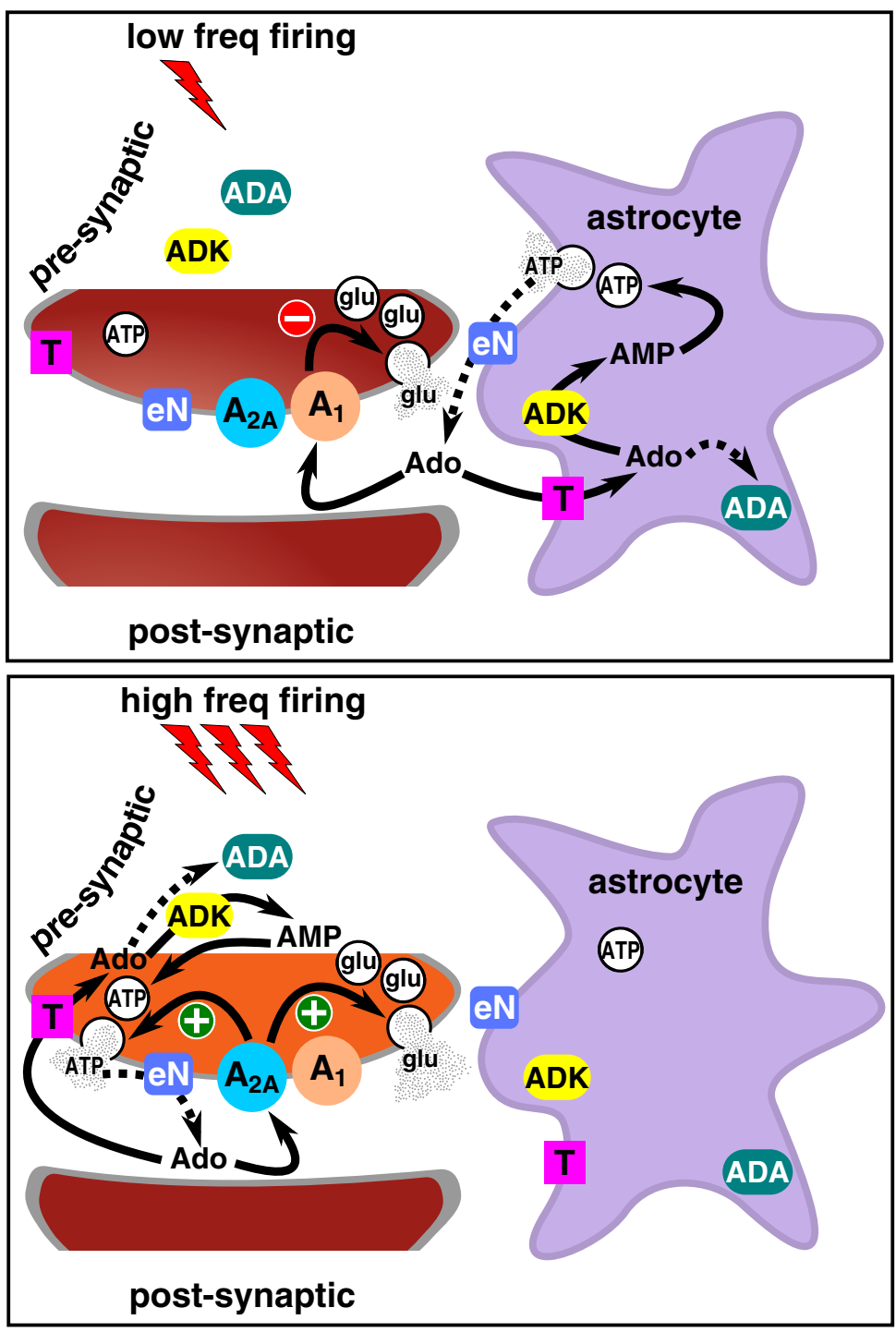

Fig. (2). Different putative role of astrocytes and nerve terminals in the recycling of adenosine at low and high frequency of stimulation. The available evidence by the group of Detlev Boison make it evident that under conditions of functioning that do not trigger synaptic plasticity, most of the scavenging and re-utilization of purine moities depends on astrocytic metabolism mainly through adenosine kinase (ADK) and eventually through adenosine deaminase (ADA), after the uptake of extracellular adenosine through nucleoside transporters (T), as shown in the upper panel. This would allow the preservation of the energetically-'expensive' purine moities by astrocytes, which also seem to be the main source of extracellular adenosine; thus under conditions of functioning that do not trigger synaptic plasticity, adenosine is formed by volume transmission-like release of ATP from astrocytes followed by extracellular catabolism by ecto-nucletidases (eN) to form extracellular adenosine mainly activating inhibitory $\mathrm{A}_{1}$ receptors in presynaptic glutamatergic nerve terminals. The situation might be different in conditions of functioning designed to trigger synaptic plasticity, such as upon high frequency stimulation. Now, there is a substantial increase in the release of ATP from nerve terminals; this ATP is extracellularly degraded by synaptic ecto-nucleotidases (eN) into adenosine, which is directed towards the activation of $\mathrm{A}_{2 \mathrm{~A}}$ receptors (expected to blunt inhibitory responses when activated, thus allowing implementation of synaptic potentiation). Since purines are released by nerve terminals, we now postulate (bottom panel) that the re-uptake and salvage of purines should mainly be carried by nerve terminals. This would allow understanding the reason why both nucleoside transporters (T), adenosine kinase (ADK) and adenosine deaminase (ADA) have also been identified in non-astrocytic compartments, mainly in nerve terminals. Furthermore, it would satisfy the energetic requirement to preserve purine moieties in the same compartments.

and coherent scenario explaining the physiological function of this system. This is what will be attempted subsequently. However, it was felt that a summary of some of the questions waiting to be experimentally tackled would emphasise the numerous caveats of this proposed hypothetic role of the adenosine neuromodulation system.

First, let's look at the role of $\mathrm{A}_{1} \mathrm{R}$ and $\mathrm{A}_{2 \mathrm{~A}} \mathrm{R}$, both of which are now clearly identified as being co-located in cortical glutamatergic nerve terminals [131]. Here it is becoming evident that $\mathrm{A}_{1} \mathrm{R}$ are a constantly working gate keeper of excessive excitatory transmission: there is an endogenous $\mathrm{A}_{1} \mathrm{R}$-mediated inhibitory tonus under most experimental conditions. This is not the case for $\mathrm{A}_{2 \mathrm{~A}} \mathrm{R}$, which do not seem to be tonically activated at lower frequencies of stimulation; $\mathrm{A}_{2 \mathrm{~A}} \mathrm{R}$ are only tonically activated at higher frequencies of nerve stimulation. Under such conditions of higher stimulation aimed at triggering plastic changes of synaptic efficiency (e.g. LTP), the $A_{1} R$ system poses a problem: since the 
higher the frequency (or intensity) of stimulation the larger the extracellular levels of adenosine $[59,110]$ and since supra-maximal activation of $A_{1} R$ can BLOCK synaptic transmission, the implementation of LTP makes it mandatory to switch off $A_{1} R$. This is one of the roles of $A_{2 A} R$, which desensitises $A_{1} R$ either through intracellular PKC-mediated pathways [76] or through the formation of $A 1-A_{2 A} R$ heteromers [77].

But how is it possible to selectively activate $\mathrm{A}_{2 \mathrm{~A}} \mathrm{R}$ only upon LTP-like conditions? The answer seems to rely on the organization of the extracellular metabolism of adenosine. Higher frequencies (or intensities) of nerve stimulation are required to trigger the release of ATP within activated synapses, whereas lower frequencies of nerve stimulation are unable to trigger a robust release of synaptic ATP (see $[109,110])$. This extracellular catabolism of this synaptic ATP (selectively in the activated synapses) is crucial to form the synaptically-localised and transient high concentrations of adenosine required to activate $\mathrm{A}_{2 \mathrm{~A}} \mathrm{R}$ [132].

In parallel, the activated synapse will also begin a process of hetero-synaptic depression involving the bolstering of $\mathrm{A}_{1} \mathrm{R}$ in neighbouring synapses (with respect to this activated synapse): the enhanced activity of the activated synapse (i.e. the synapse undergoing a plastic change) will trigger the activation of the astrocytic syncytium [61]; within the domain covered by this syncytium, there will be a greater astrocytic release of ATP (i.e. non-synaptic), which will be degraded by ecto-nucleotidases (probably different from the synaptic ecto-nucleotidases responsible for generating the adenosine required for activation of $\mathrm{A}_{2 \mathrm{~A}} \mathrm{R}$ ) degrading ATP into the adenosine which is channelled into $A_{1} R$ [58], further depressing the activity of neighbouring synapses.

Thus, the concerted activation of $\mathrm{A}_{1} \mathrm{R}$ and $\mathrm{A}_{2 \mathrm{~A}} \mathrm{R}$ can encode information salience in brain circuits: the selective release of synaptic ATP in the activated synapse allows a selective engagement of $A_{2 A} R$, which switch off $A_{1} R$ (and $\mathrm{CB}_{1} \mathrm{R}$ ) allowing implementation of potentiation in the activated synapse; simultaneously, this activated synapse recruits the astrocytic syncytium to enhance $A_{1} R$ mediated inhibition in all neighbouring (non-activated) synapses (where $A_{2 A} R$ is not engaged). Thus, the combined and coordinated function of $\mathrm{A}_{2 \mathrm{~A}} \mathrm{R}$ only in the activated synapse and of $A_{1} R$ in all other surrounding synapses, allows enhancing the signal to noise ratio in the activated synapse versus surrounding background, i.e. salience (see Fig. 3).

A final word to discuss the termination of the signal: here, we hypothesise that there is a tight interaction between receptors and transporters (e.g. [133]). Since most of the adenosine probably originates from astrocytic-derived ATP [62], metabolic saving and compartmentalization makes it logical that the clearance should be made by astrocytic AdoT; then, it would be expected that ADK should play a major role, since deamination of adenosine yields ammonia, one of the strongest toxins for brain functioning. The situation might be slightly different in the activated synapse: here ATP is released mostly from nerve terminals, so metabolic saving and compartmentalization (in the absence of a documented purine shuttling between astrocytes and neurons) dictates that adenosine should be re-uptaked by nerve terminals. Ideally, one should expect that $\mathrm{A}_{2 \mathrm{~A}} \mathrm{R}$ should also bolster the activity of synaptic AdoT, so that the uptake of adeno- sine in nerve terminals is only engaged when $\mathrm{A}_{2 \mathrm{~A}} \mathrm{R}$ are recruited (to avoid diverting purines released from astrocytes into nerve terminals); interestingly, neurochemical studies [133] support this scenario (see Fig. 2), which still waits for functional confirmation.

\section{CLASSICAL VIEW ON THE ABILITY OF PURINES TO CONTROL EPILEPSY}

Since the activation of $A_{1} R$ seems the most evident effect of adenosine and it selectively decreases excitatory rather than inhibitory transmission $[45,46]$, inhibits calcium influx through voltage sensitive calcium channels and also inhibits NMDA responses, adenosine acting through $A_{1} R$ have long been considered an endogenous neuroprotective system [134]. Furthermore, the ability of $A_{1} R$ to hyperpolarise principal neurons further suggests that adenosine acting through $\mathrm{A}_{1} \mathrm{R}$ should be a major anti-epileptic system [135]. In accordance with this idea, numerous studies have documented that the acute administration of either agents enhancing the extracellular levels of adenosine (inhibitors of AdoT, inhibitors of ADA or inhibitors of $\mathrm{ADK}$ ) or agonists of $\mathrm{A}_{1} \mathrm{R}$ curtail seizure and/or convulsive activity in different animal models (reviewed in [18,135-137]); conversely, the acute administration of either selective $\mathrm{A}_{1} \mathrm{R}$ antagonists or non-selective antagonists of adenosine receptors (such as caffeine or theophylline) enhance the duration and severity of seizures and/or convulsions (reviewed in [18,135-137]). Furthermore, there is evidence that the levels of endogenous extracellular adenosine rise at the onset of seizure activity, both in animal models (e.g. [138]) as well as in humans [139]). Thus, it seems evident that in a naïve system, $\mathrm{A}_{1} \mathrm{R}$ effectively constitute a hurdle curtailing seizure activity. This is confirmed by the ability of $\mathrm{A}_{1} \mathrm{R}$ to control the spreading of seizure activity [140] and the greater susceptibility of $A_{1} R$ knockout mice to epilepsy [140-142].

However, although it is generally assumed that the inhibition of excitatory transmission and the hyperpolarisation of principal neurons might represent the mechanism of $A_{1} R$ mediated anti-epileptic-like effects, this has not been conclusively demonstrated. The most perturbing evidence lies in the combined observation that there is a decreased density and efficiency of synaptic $\mathrm{A}_{1} \mathrm{R}$ in models of epilepsy [143146], whereas there is robust evidence showing that $A_{1} R$ are still able to efficiently control chronic epileptic-like conditions [19] and even pharmaco-resistant forms of epilepsy [147]. Furthermore, there is direct evidence showing a dissociation between the ability of $\mathrm{A}_{1} \mathrm{R}$ to control glutamatergic transmission and to prevent pilocarpine-induced seizures [148,149].

Finally, the last set of data perturbing the long established idea that adenosine is an endogenous anti-epileptic substance relies on the use of long term caffeine consumption. Caffeine is a non-selective antagonist of $\mathrm{A}_{1} \mathrm{R}$ and $\mathrm{A}_{2 \mathrm{~A}} \mathrm{R}$ (and likely of other adenosine receptors) and its established mechanism of action at non-toxic doses is the antagonism of these receptors [150]. The long term consumption of moderate doses of caffeine $(0.3 \mathrm{~g} / \mathrm{L})$ was found to prevent neuronal damage in different models of epilepsy [151-153]. Thus, in spite of the ability of chronic caffeine consumption to upregulate cortical $\mathrm{A}_{1} \mathrm{R}[154,155]$, the partial but chronic blockade of adenosine receptors by caffeine reveals a benefi- 

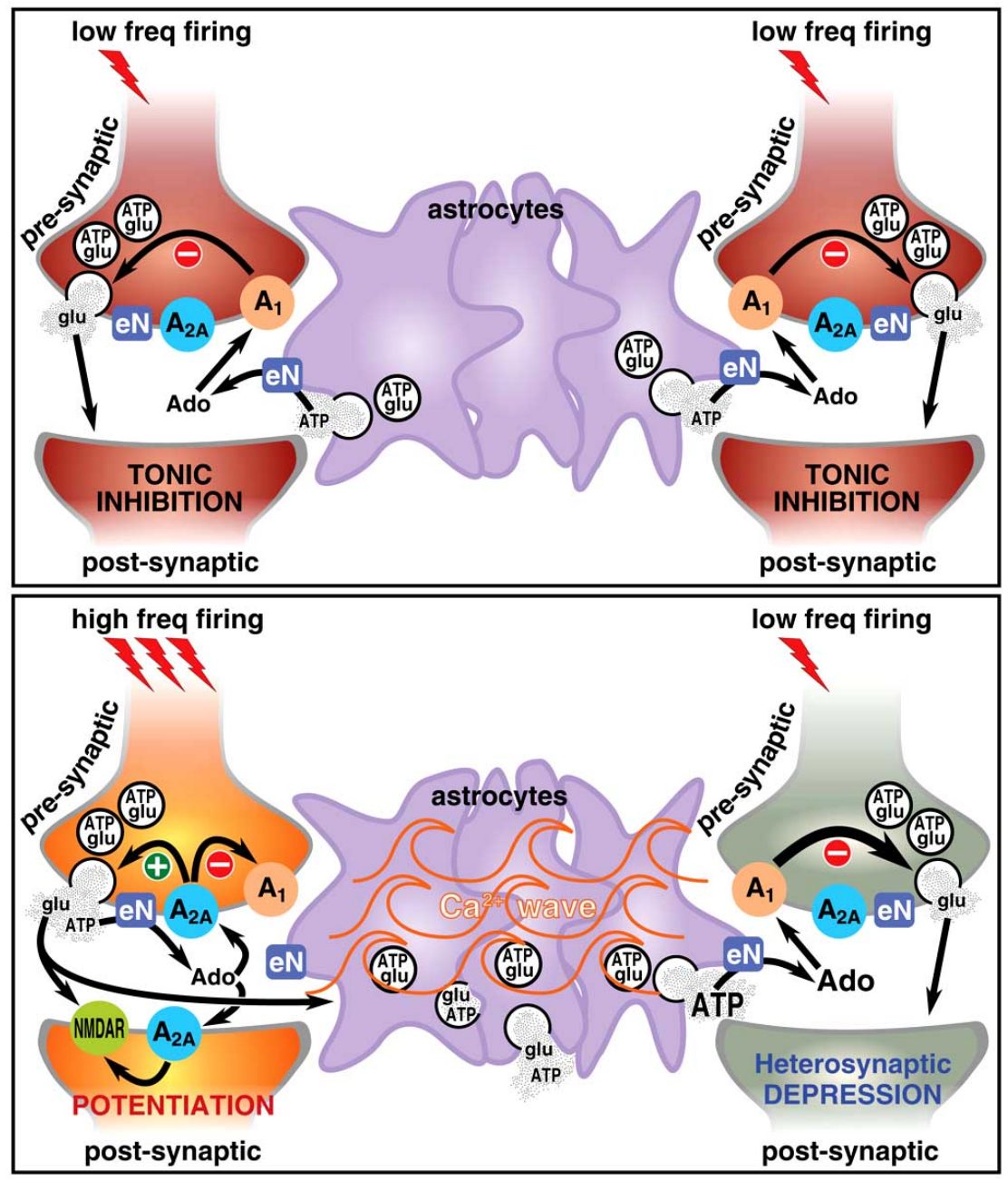

Fig. (3). Coordinated role of adenosine $A_{1}$ and $A_{2 A}$ receptors to assist encoding information salience in brain networks. At low frequencies of stimulation (i.e. conditions of functioning of neuronal circuits that do not trigger synaptic plasticity), there is mostly a volume transmission-like release of ATP from astrocytes throughout the whole neuronal network covered by the astrocytic syncytium; this extracellular ATP is catabolised by peri-synaptic (neuronal non-synaptic or astrocytic) ecto-nucletidases (eN) to form extracellular adenosine mainly activating inhibitory $\mathrm{A}_{1}$ receptors in all presynaptic glutamatergic nerve terminals covered by the astrocytic syncytium (upper panel). Thus, this global and homogenous inhibitory tonus imposed by the tonic activation of inhibitory $\mathrm{A}_{1}$ receptors can be viewed as a hurdle to restrain excessive activity in any particular excitatory synapse of the network. The situation is different when one particular excitatory synapse in the network undergoes a plastic change. For instance, if a synapse is undergoing the implementation of a long-term potentiation through high frequency firing, this activated synapse will release substantial amounts of ATP that are locally (only in the activated synapse) converted into adenosine, which is directed to the activation of facilitatory $\mathrm{A}_{2 \mathrm{~A}}$ receptors presynaptically blunting other inhibitory modulation systems (such as these operated by adenosine $A_{1}$ or cannabinoid $C_{1}$ receptors) and postsynaptically facilitating the recruitment of NMDA receptors. This effectively allows the activated synapse to undergo potentiation (left synapse of bottom panel). In parallel, the activated synapse will trigger astrocytic activation (e.g. 'C $\mathrm{Ca}^{2+}$ waves'), which will enhance vesicular release of gliotransmitters, namely ATP, in all neighbouring synapses covered by the activated astrocytic syncytium. Thus, as described above, there will be a greater inhibitory tonus in all neighbouring synapses when the 'activated' synapse is undergoing potentiation. This simultaneous $\mathrm{A}_{2 \mathrm{~A}}$ receptor-mediated facilitation of potentiation in the 'activated' synapse with parallel enhanced $\mathrm{A}_{1}$ receptor-mediated inhibition through astrocytic-mediated heterosynaptic depression of all neighbouring synapses allows proposing that the adenosine neuromodulation system is involved in the encoding of salience of information in neuronal networks.

cial effect on seizure-induced neuronal damage. Altogether, these evidences warn for the need to re-evaluated different facets of the adenosine neuromodulation system in the realm of the control of convulsive activity and associated neurodegeneration.

\section{ALTERNATIVE MECHANISMS ASSOCIATED WITH THE CONTROL OF 'EPILEPSY' BY PURINES}

There are three situations that need to be clearly disentangled: 1) on one hand, one needs to consider the role of the adenosine neuromodulation system in the control of the 'first' seizure episode in an otherwise naïve animal; 2) there is also the need to consider the situation closer to that found in epileptic patients, i.e. individuals who already suffered several previous noxious insults (previous seizures, trauma or others) and who have already undergone an adaptive period (of epileptogenesis) that renders them more susceptible for subsequent seizures; 3) finally, a particular focus will be dedicated to the neurodegeneration that can follow a severe period of convulsive activity; here the focus is not on the 


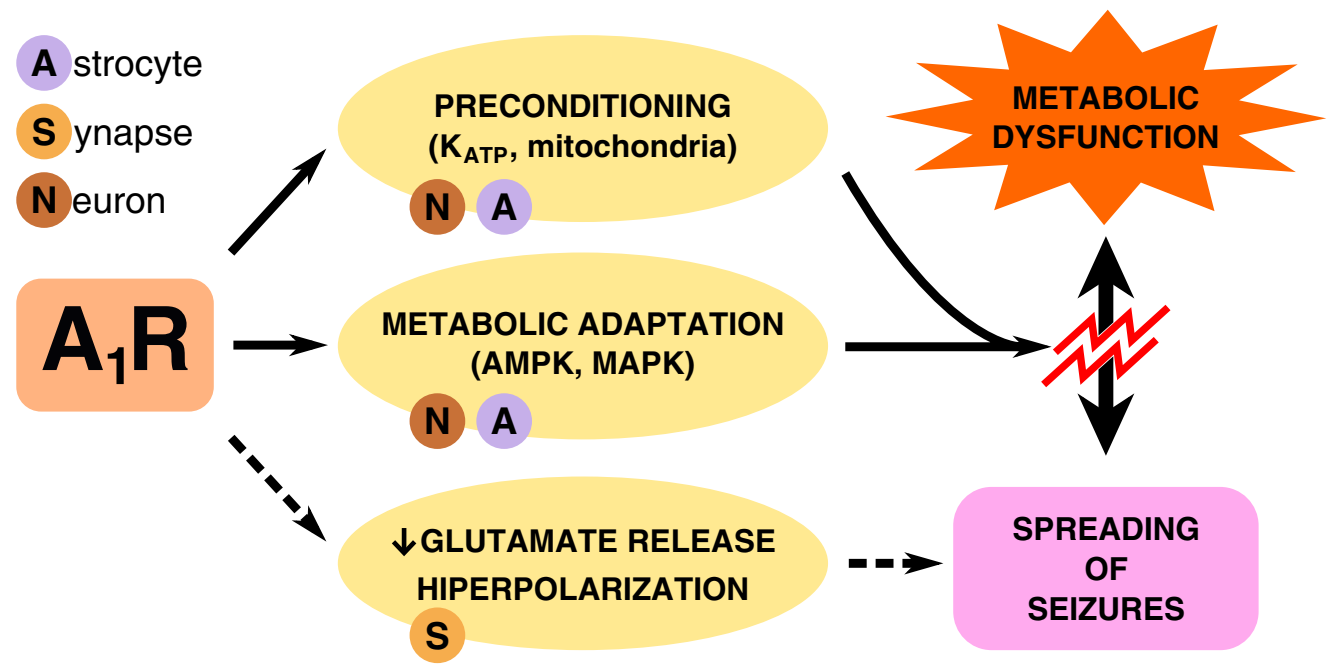

Fig. (4). Possible candidate mechanisms operated by adenosine $A_{1}$ receptors to control the spreading of seizure activity and associated neurodegeneration. Adenosine $A_{1}$ receptors have been shown to act as hurdle preventing the spread of neuronal damage; this might be achieved through the ability of $A_{1}$ receptors to affect mitochondrial function upon control of ATP-activated potassium channels $\left(\mathrm{K}_{\mathrm{ATP}}\right)$. Accordingly, modifiers of $\mathrm{K}_{\mathrm{ATP}}$ function or of their impact on mitochondria affect $\mathrm{A}_{1}$ receptor-mediated neuroprotection and also affect 'epilepsy' and associated neurodegeneration. In parallel, other studies have shown the ability of $A_{1}$ receptors to affect both neuronal and astrocytic metabolism. Accordingly, it has been proposed by Jonathan Geiger and Susan Masino that adenosine might be a key mediator of the impact of ketogenic diets on brain neurodegeneration and epilepsy. Thus, it is possible that $\mathrm{A}_{1}$ receptor-mediated metabolic adaptation may play a key role in the $A_{1}$ receptor-mediated neuroprotection. Finally, there is solid electrophysiological evidence to sustain a direct $A_{1}$ receptor-mediated control of the release of glutamate and of the frequency of firing of principal neurons. Although this can potentially assist in controlling excitability, there is a lack of direct evidence showing that this direct control of transmission and excitability of glutamatergic neurons are actually the basis of $\mathrm{A}_{1}$ receptor-mediated control of seizure activity and associated neuroprotection.

control of seizures themselves but rather of the ensuing mechanisms of neurodegeneration triggered by seizures.

The answer to the first question seems well consolidated experimentally, as described in the first paragraph of the previous section. The $\mathrm{A}_{1} \mathrm{R}$-operated inhibitory system seems to act as a continuously active gate-keeper or hurdle to avoid initiating a seizure-like event. We will now focus on the adaptive mechanisms suffered by the adenosine neuromodulation system in 'chronic' models of epilepsy, before looking in a provocative manner at neurodegeneration in the next section.

\section{4a. How 'Epilepsy' Modifies the $A_{1}$ Receptor Inhibitory System}

When considering the $\mathrm{A}_{1} \mathrm{R}$-mediated inhibitory system, there seems to be a decreased density of $A_{1} R$ in chronic models of epilepsy [143-146]. This is particularly evident when looking at nerve terminals $[143,156]$ and is accompanied by a decreased ability of $A_{1} R$ to modulate excitatory synaptic transmission [143]. This decreased density and functioning of synaptic $\mathrm{A}_{1} \mathrm{R}$ contrasts with the observation that an experimentally imposed elevation of endogenous extracellular adenosine is still effective to control the spreading of seizures $[19,140]$, namely in pharmaco-resistant animal models of epilepsy [147]. This allows two conclusions: first, that there is indeed a long-term desensitization of $A_{1} R$ in chronic models of epilepsy, in line with the general desensitization of $A_{1} R$ in chronic neurodegenerative disease (reviewed in [40]); the second conclusion is that this desensitization does not seem to completely abrogate the potential inhibitory action of $\mathrm{A}_{1} \mathrm{R}$ to control seizure activity. Probably, the greatest contributing factor for decreased function of the endogenous $\mathrm{A}_{1} \mathrm{R}$-mediated inhibitory system might be the lack of adequate adenosine receptor tonus, which might be a result of the modified purinergic metabolism [19,157].

In fact, several modifications of purinergic metabolism have been reported to occur in chronic animal models of epilepsy. During seizure activity there is an increase in the extracellular levels of adenosine [138,139]. However, after the occurrence of repetitive periods of seizure activity and in the absence of seizure activity, there seems to be lower levels of extracellular adenosine [143]. This is probably due to the robust increase of the expression and activity of ADK mainly in astrocytes [126,127], which seems to be a key event in the re-adaptation of the adenosinergic system [19]. Therefore, albeit there is a decrease in the density of presynaptic $A_{1} R$, their activation may still be an attractive and effective manner to restrain subsequent seizure activity in models of chronic 'epilepsy'; this might be better achieved by manipulating $A D K$ rather than directly activating $A_{1} R$ using $A_{1} R$ agonists since the latter have profound cardiovascular peripheral effects [158].

\section{4b. Possible Mechanisms Operated by $A_{1}$ Receptors to Manage Chronic 'Epilepsy'}

The fact that indirectly targeting $\mathrm{A}_{1} \mathrm{R}$ through enhancement of endogenous extracellular adenosine is remarkably effective to control seizure activity in animal models of chronic epilepsy, in spite of the decreased density and function of presynaptic $A_{1} R$, strongly suggests that the ability of $A_{1} R$ to control seizures in epileptic conditions might be unrelated to the synaptic roles of $\mathrm{A}_{1} \mathrm{R}$ (see Fig. 4). In fact, it is conceivable that the ability of $A_{1} R$ to prevent seizure and convulsive activity might be related to non-synaptic $A_{1} R$. 
One possibility is that $A_{1} R$ might control intermediary metabolism, which is well known to be crucial to sustain seizure activity [159] and is decisive to determine neuronal degeneration [160-162]. In fact, besides acting as a neuromodulator, adenosine also fulfils a general homeostatic role controlling intermediary metabolism, which is considered the basis of the non-brain tissue protective effects afforded by extracellular adenosine (reviewed in [104]): $A_{1} R$ activation is not only able to preserve the viability of the nervous system subject to insults, but can also afford protection of several other tissues to injury, such as the heart, kidney or liver [163-167]. This clearly indicates that $A_{1} R$ might protect eukaryotic cells through a common general mechanism which is obviously broader than synaptic effects, albeit these synaptic effects might also contribute to the protection of the nervous system.

However, the way by which $\mathrm{A}_{1} \mathrm{R}$ might impact on metabolism is still poorly characterised. For instance the cardioprotective effect of adenosine is related to the ability of $\mathrm{A}_{1} \mathrm{R}$ activation to control glucose and glycogen metabolism [168-171]. Adenosine also affects both brain neuronal and astrocytic intermediary metabolism [63,172-176]. In particular, $\mathrm{A}_{1} \mathrm{R}$ can affect AMPK [177], p38 MAPK [178-181] or preserve mitochondria function through control of $\mathrm{K}_{\mathrm{ATP}}$ channels [182-186]; these are all pathways known to coordinate primary metabolism and to have a profound impact on neuronal function and viability [187-189]. However, an integrative picture relating $A_{1} R$ activation and the putative recruitment of each of these candidate transducing pathways in the realm of neuroprotection has still not been put forward.

The involvement of $A_{1} R$ in the phenomena of preconditioning of brain tissue [64] provides another hypothetic avenue to understand the impact of this modulation system in the control of epilepsy. Preconditioning is a process whereby a short sub-threshold (or mild noxious) insult affords a sustained protection against a subsequent more intense noxious stimulus. Brain preconditioning is receiving increasing clinical attention especially in the case of stroke [190], but it is also known that sustained epileptic seizures confer a substantial temporary protection against the cellular damage induced by subsequent epileptic challenge, a phenomena called 'epileptic tolerance' [191, 192]. Brain preconditioning involves a cascade of metabolic adaptive pathways which depends on a coordinated response at the genomic, molecular, cellular and tissue levels [193-196]. Preconditioning is associated with a metabolic down-regulation mainly orchestrated by modified mitochondrial functioning [197], which is known to afford a general better coping with insults [198]; in the nervous system, preconditioning involves coordinated modifications of neurons and astrocytes (see [199]) and modification of the signalling by inflammatory-related molecules (e.g. [200201]) and neurotrophins (e.g. [202]). Interestingly, all these responses $\left(\mathrm{K}_{\mathrm{ATP}}\right.$, mitochondria, metabolism, neuroinflammation and neurotrophin actions) can potentially be controlled by the adenosine neuromodulation system (reviewed in [40]). Furthermore, $A_{1} R$ have been identified as a key signalling system to mediated brain preconditioning [64, 203-205], in particular epileptic preconditioning [206,207]. This paves the way to consider this $\mathrm{A}_{1} \mathrm{R}$-mediated preconditioning as a likely candidate mechanism to understand the 'anti-epileptic' potential of $A_{1} R$. An hypothetic scenario can be advanced, based on a coordinated action between different adenosine receptors and between neurons and astrocytes (see Fig. 5): thus, the initiation of seizure activity increases the extracellular levels of adenosine $[138,139]$; this adenosine can activate astrocytic adenosine receptors further increasing adenosine release through ATP-mediated spreading depression [174,208,209] and through increases of interleukin-6 mRNA expression and release [210,211]; spreading of this activation 'wave' through the astrocytic syncytium would allow a simultaneous increase of adenosine as well as a bolstering of $\mathrm{A}_{1} \mathrm{R}$ expression and density, promoted by interleukin-6 $[212,213]$ in neurons adjacent to the seizure foci. Overall, this should contribute to limit seizure spreading, through synaptic $\mathrm{A}_{1} \mathrm{R}$ and to allow neighbouring neurons to better cope with seizures through metabolic down-regulation. In case of astrocytic dysfunction, this preconditioning would be lost and spreading seizures and neurodegeneration could arise, as has been proposed to occur upon brain ischemia [199]. This places again astrocytes at the core of modifications in epilepsy, as tentatively proposed by Detlev Boison [19,157,214] (see also [15-17]). It is hoped that future studies may test the likeliness of this hypothetic scenario.

\section{4c. Possible Role of Adenosine $A_{2 \mathrm{~A}}$ Receptors}

Although the major interest of the adenosine neuromodulation system has been the inhibitory $A_{1} R$ system, an increasingly number of studies are now focusing on facilitatory $A_{2 A} R$. In fact, these $A_{2 A} R$ have received considerable attention in recent years since their pharmacological and genetic blockade confer neuroprotection against different noxious brain conditions $[215,216]$. Albeit $\mathrm{A}_{2 \mathrm{~A}} \mathrm{R}$ have a discrete density in the non-injured cortex [217], their density increases considerably after noxious stimuli [40,215] for reasons and through mechanisms still to be clarified. In particular, upon chronic epilepsy there is a robust increase (over 200\%) of the density of $A_{2 A} R$ [156]. In accordance with this scenario, the impact of $\mathrm{A}_{2 \mathrm{~A}} \mathrm{R}$ on the onset of seizure activity is still disputable [218-225]. However, recent elegant studies make it evident that the blockade of $\mathrm{A}_{2 \mathrm{~A}} \mathrm{R}$, either using genetic deletion of $A_{2 A} R$ [226] or selective $A_{2 A} R$ antagonists [225,227] or non-selective antagonists such as chronic caffeine administration [227] can afford robust protection against the seizure evolving severity. Furthermore, chronic caffeine administration or $\mathrm{A}_{2 \mathrm{~A}} \mathrm{R}$ blockade effectively prevent neuronal damage following convulsions [151-153,228] and seem to be a general indicator of favourable prognosis in diseases involving neurodegeneration $[229,230]$. Thus, $\mathrm{A}_{2 \mathrm{~A}} \mathrm{R}$ seem to control the evolution and consequences of seizures, both seizurebeget-seizure and seizure-induced neurodegeneration.

It is currently not known the mechanisms by which $\mathrm{A}_{2 \mathrm{~A}} \mathrm{R}$ blockade confers such a robust neuroprotection [215,216] (see Fig. 6). This has been proposed to result from the ability of $\mathrm{A}_{2 \mathrm{~A}} \mathrm{R}$ to control the seizure-induced delayed outflow of glutamate [148,149]. Thus, given that $\mathrm{A}_{2 \mathrm{~A}} \mathrm{R}$ are densely located in glutamatergic synapses [131] where they control the release of glutamate [74-77] and the activation of NMDA receptors [78,231-233], one possibility would be that $A_{2 A} R$ could control glutamate-mediated excitotoxicity. This has received indirect support from studies showing that $\mathrm{A}_{2 \mathrm{~A}} \mathrm{R}$ blockade protects from: 1) the initial synaptotoxicity that occurs after exposure to $\beta$-amyloid $1-42$ peptide [234], a putative causative factor of Alzheimer's disease [235]; 2) the initial synaptotoxicity that accompanies 


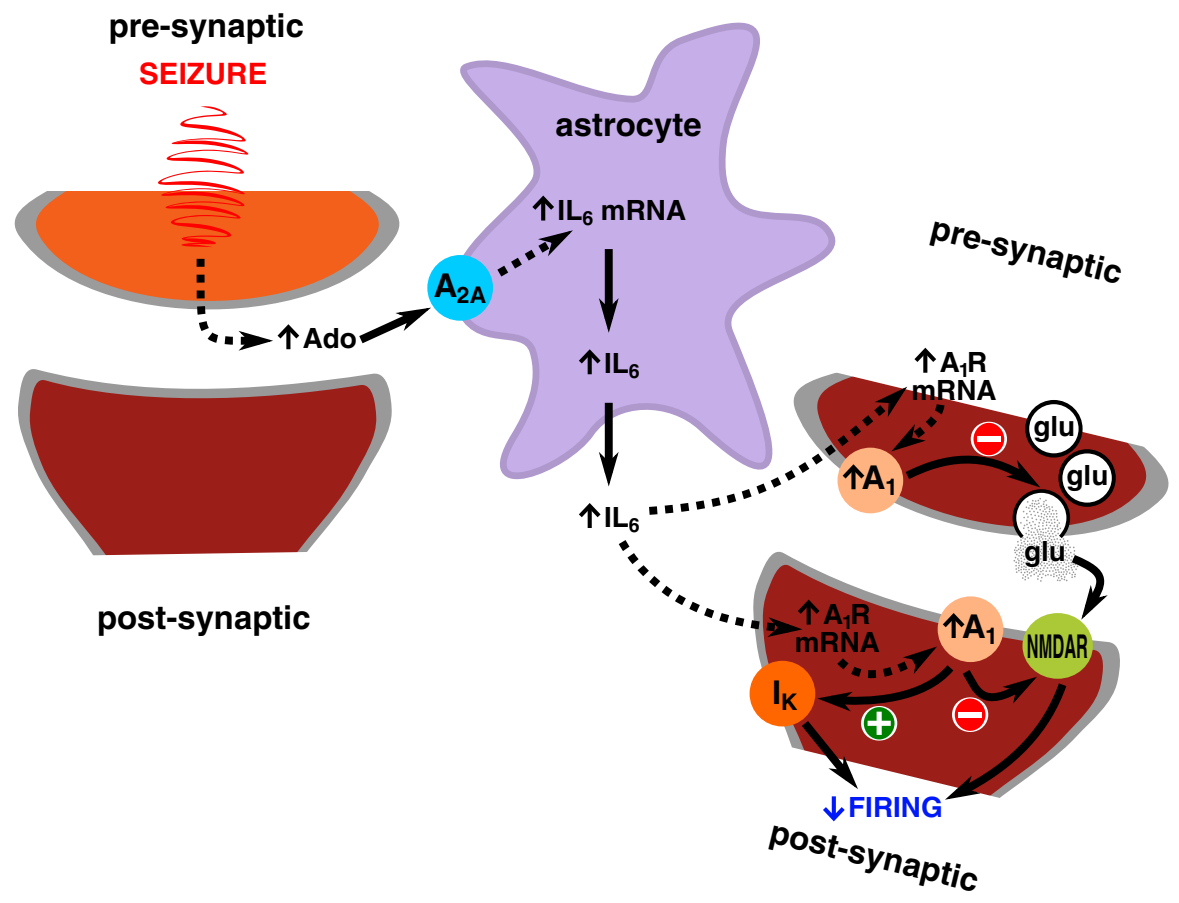

Fig. (5). Proposed central role of astrocytes in regulating the adaptive strength of the 'anti-epileptic' adenosine $A_{1}$ receptor-mediated inhibitory system. There is increased evidence that astrocytes play a key role in formatting the adenosine neuromodulation system in epilepsy. Detlev Boison championed the proposal that the enhanced activity of adenosine kinase in astrocytes was a key event contributing to the loss of $A_{1}$ receptor-mediated neuroprotection. Here, we argue that astrocytes may also have a parallel role bolstering $A_{1}$ receptor-mediated inhibition in the initial phases of spreading of seizure activity. This would rely on the known ability of $\mathrm{A}_{2}$ receptors to enhance the expression and release of interleukin 6 (IL-6) in astrocytes, which would be enhanced upon seizure activity by the higher levels of adenosine. Furthermore, the group of Knut Biber has shown that IL-6 can enhance the expression and synaptic function of $A_{1}$ receptors, which would assist the control of spreading seizures. This hypothetic role of astrocytic-neuron communication involving both $A_{1}$ and $A_{2}$ receptors might also be applied in the case of glucorcorticoids, which expression is also enhanced upon seizures and which may bolster $A_{1}$ receptor expression, as shown by Per Svenningsson and Bertil Fredholm.

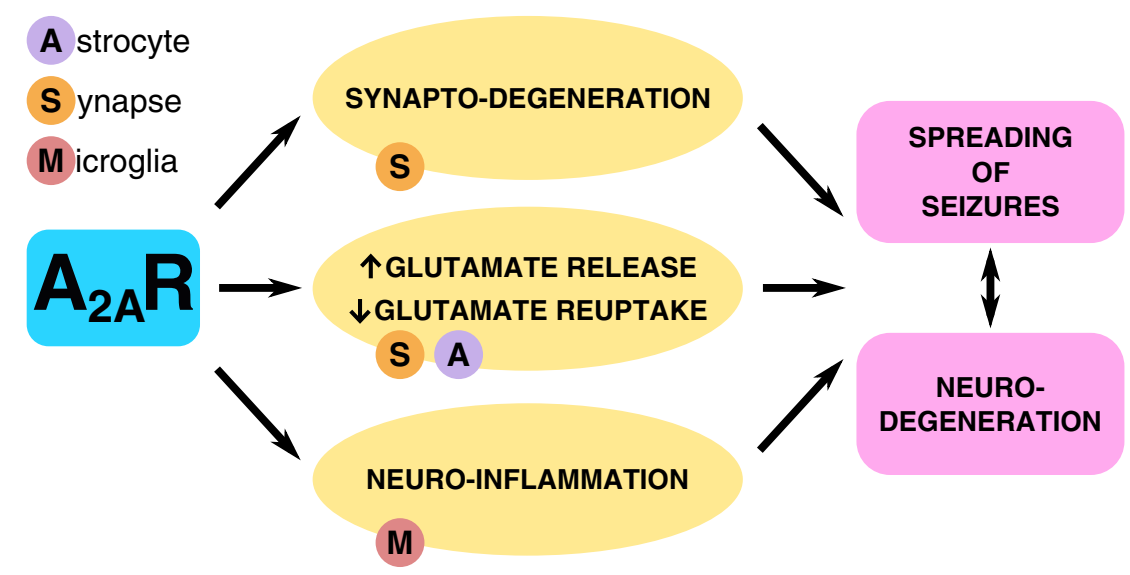

Fig. (6). Possible mechanisms operated by adenosine $A_{2 A}$ receptors to control the spreading of seizure activity and resulting neurodegeneration. Adenosine $\mathrm{A}_{2 \mathrm{~A}}$ receptors are mostly located in synapses, namely in excitatory synapses of the limbic cortex. Their blockade has been shown to prevent the loss of synaptic markers in different models of neurodegeneration, suggesting that $\mathrm{A}_{2 \mathrm{~A}}$ receptors play a key role in controlling one of the early features found to depress the functioning of limbic circuits in different neurodegenerative diseases. $\mathrm{A}_{2 \mathrm{~A}}$ receptors have also been found to control the release of glutamate, the activity of glutamate transporters and the activation of NMDA receptors; these may be potential mechanisms explaining the ability of $\mathrm{A}_{2 \mathrm{~A}}$ receptors to control synaptic degeneration or may constitute a parallel mechanism by which $\mathrm{A}_{2 \mathrm{~A}}$ receptors control excessive glutamatergic transmission involved both in the spreading of seizures as well as on the associated neurodegeneration. Finally, $A_{2 A}$ receptors also control neuroinflammation, another feature exacerbated by seizure activity and known to contribute to the expression of neurodegeneration. Albeit not exclusive nor the only possible mechanisms, these are processes that allow understanding the effectiveness of $\mathrm{A}_{2 \mathrm{~A}}$ receptor antagonists (or of chronic caffeine consumption) to prevent neurodegeneration in different animal models of epilepsy. 
memory impairment in adult rats subject to a single convulsive period in their early life [236]. Also, studies in cultured neurons (i.e. essentially devoid of glial or vascular elements) also showed that $\mathrm{A}_{2 \mathrm{~A}} \mathrm{R}$ blockade affords neuroprotection against $A \beta_{1-42}$ or staurosporine [234,237]. Furthermore, $A_{2 A} R$ blockade preserved the viability of purified nerve terminals directly exposed to either $A \beta_{1-42}$ or staurosporine [234,237], which strongly supports a direct ability of synaptic $\mathrm{A}_{2 \mathrm{~A}} \mathrm{R}$ to control synaptic viability. However, these studies do not rule out other non-synaptic mechanisms to explain the neuroprotection associated with $\mathrm{A}_{2 \mathrm{~A}} \mathrm{R}$ blockade. Thus, $\mathrm{A}_{2 \mathrm{~A}} \mathrm{R}$ are also located in astrocytes and microglia cells [238-240], where they can control glutamate clearance [94,241], the expression and action of trophic factors [242-245] and neuroinflammation [238,244,246,247]. Furthermore, $\mathrm{A}_{2 \mathrm{~A}} \mathrm{R}$ were also recently found to be present in oligodendrocytes, controlling their degeneration upon ischemia [248]. Probably both neuronal and non-neuronal mechanisms contribute to the ability of $\mathrm{A}_{2 \mathrm{~A}} \mathrm{R}$ to control neurodegeneration, according to their temporal pattern of recruitment: for instance, using the MPTP animal model of Parkinson's disease, it has been shown that damage caused by administration of higher doses of MPTP (causing a rapid neurodegeneration) is prevented by non-neuronal $\mathrm{A}_{2 \mathrm{~A}} \mathrm{R}$ blockade [240], whereas damage caused by administration of lower doses of MPTP (causing a slow and insidious neurodegeneration) is instead prevented by the genetic deletion of neuronal $A_{2 A} R$ [249]. There might also be an additional contribution from $A_{2 A} R$ in cells other than neurons or glia: for instance, in the case of ischemic models, there is a contribution of neuronal $\mathrm{A}_{2 \mathrm{~A}} \mathrm{R}$ as well as of $\mathrm{A}_{2 \mathrm{~A}} \mathrm{R}$ located in peripheral myeloid derived cells [250]. Recent studies also found a striking ability of caffeine to control the integrity and functionality of the blood brain barrier [251,252], which is likely to be an effect operated by the abundant endothelial $A_{2 A} R$. Finally, given the role of $A_{2 A} R$ in controlling cerebral vessels [253-258], it is possible that the $\mathrm{A}_{2 \mathrm{~A}} \mathrm{R}$-mediated vascular control might also contribute to neuroprotection.

Interestingly, the source of the adenosine proposed to preferentially activate $\mathrm{A}_{2 \mathrm{~A}} \mathrm{R}$ (ATP-derived adenosine formed through the ecto-nucleotidase pathway) is also modified in 'epileptic' rodents: thus, there is a lower release of ATP and a modified extracellular catabolism of ATP [143,259-262]; but more importantly, there is an augmentation of the density and activity of ecto-5'-nucleotidase [143,261-264], which is often the rate-limiting step in the formation of adenosine from extracellular ATP [99,265]. Thus, on epilepsy there seems to be an up-regulation of $\mathrm{A}_{2 \mathrm{~A}} \mathrm{R}$ as well as of the source of adenosine activating them and $\mathrm{A}_{2 \mathrm{~A}} \mathrm{R}$ blockade seems to afford beneficial effects.

\section{4d. Possible Role of ATP and $P_{2}$ Receptors in Epilepsy}

ATP was so far only considered as a source of adenosine. However, this is only one of its several possible roles since extracellular ATP is also a signalling molecule with diverse and important functions, which were elegantly reviewed by the 'father' of the purinergic field, Geoffrey Burnstock (e.g. [266]). Thus ATP can be released by virtually all cell types and can signal through a large family of receptors $\left(\mathrm{P}_{2}\right.$ receptors, $\mathrm{P}_{2} \mathrm{R}$ ) encompassing both ionotropic $\mathrm{P}_{2 \mathrm{X}} \mathrm{R}$ and metabotropic $\mathrm{P}_{2 Y} \mathrm{R}$ [266]. These receptors are located in most cell types in the brain, namely in neurons, astrocytes, microglia and oligodendrocytes, which makes ATP a prototypical transcellular signalling molecule between all major cell types in the brain (see Fig. 7). Thus, ATP can fulfil a variety of functions in the central nervous system, such as neurotransmitter [267,268], neuromodulator [269,270], gliotransmitter affecting neurons [271,272] and allowing propagation of astrocytic calcium waves [273,274], inflammatory mediator (trigger and amplifier) [275,276], trophic factor [277,278] and controller of stem cell migration, differentiation and neurogenesis [279,280]. Since each of these different roles ascribed to ATP is associated with different epileptic conditions as well as with different neurodegenerative conditions, it is likely that an abnormal functioning of the ATP signalling system might contribute to the development of brain dysfunction (reviewed in [266,272,281,282]).

The loss of viability of eukaryotic cells results in rupture of its plasma membrane with the consequent release of its intracellular content; since ATP is one of the most abundant molecules in eukaryotic cells, the rupture of the plasma membrane will cause a massive increase in the extracellular levels of ATP. In contrast to the controlled release of ATP in physiological conditions, this large release of ATP is designed to act as a main danger signal, i.e. as a molecule able to signal to neighbouring cells a situation of distress, a concept first proposed by Francesco di Virgilio in the control of inflammation [283]. This role of ATP as a danger signal also seems to occur in the central nervous system where a large and sustained release of ATP is observed in the periphery of a lesioned region in the spinal cord [284,285]. It was also reported that ATP levels increase upon ischemia in the striatum [286], but it was not made clear if this occurred in the infarcted or peri-infarcted region. Interestingly, some reports already indicate that general antagonists of $\mathrm{P}_{2} \mathrm{R}$ can attenuate both spinal cord injury [284,287] as well as ischemic damage [288,289]. Thus, ATP may also fulfil a double-edge swordlike function in the brain, as it does in the inflammatory system [283]: first to signal danger and orchestrating a series of adaptive responses designed to cope with the potential damaging insult and to initiate tissue repair; however, this signalling becomes deleterious if inappropriately sustained, thus contributing to amplify tissue damage. Thus, in the injured brain, the inappropriately large release of ATP and sustained activation of $\mathrm{P}_{2} \mathrm{R}$ can contribute to neurodegeneration through direct toxic actions to neurons, spreading of astrocytic calcium waves and triggering neuroinflammation [266,272,274,281,282]. In parallel, the modified expression and density of both $\mathrm{P}_{2 \mathrm{X}} \mathrm{R}$ and $\mathrm{P}_{2 \mathrm{Y}} \mathrm{R}$ observed in different cell types in different noxious brain conditions might also contribute to deregulate reparative processes (reviewed in $[266,281,282])$. Thus, as has been unravelled for the control of peripheral inflammation, it is becoming evident that the disruption of the ATP/ $\mathrm{P}_{2} \mathrm{R}$ system in the central nervous system may also contribute to impaired brain function and neurodegeneration.

In the particular case of epilepsy, there are still no direct reports of the role of the $\mathrm{ATP} / \mathrm{P}_{2} \mathrm{R}$ system (see [290]), albeit it has been shown that there are modified levels of ATP [291], altered evoked release of ATP [143], different stability of extracellular ATP (i.e. modification of the activity of ecto-nucleotidases) $[143,261,262]$ and a modification of the 


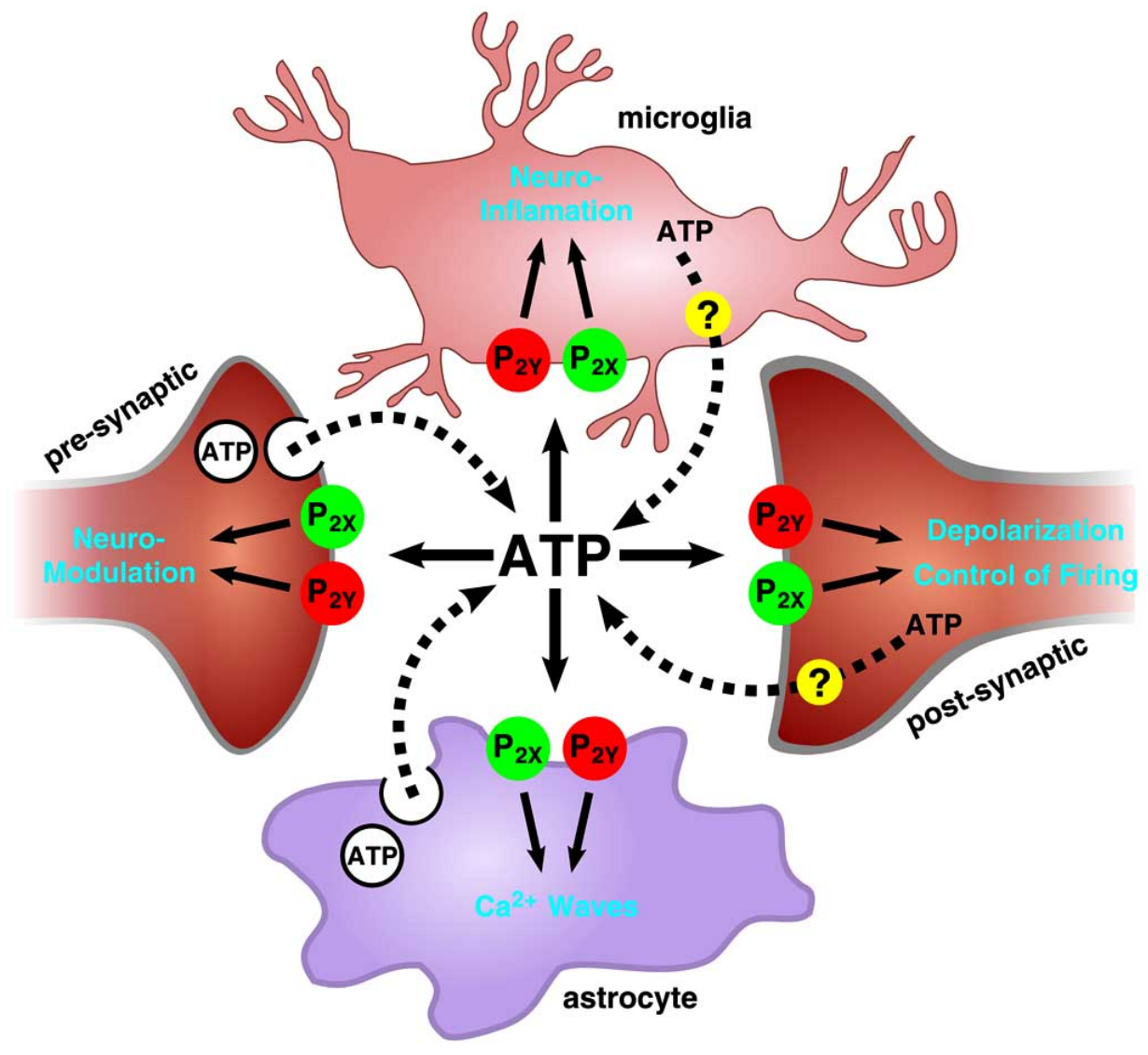

Fig. (7). The major cell types in brain tissue can release ATP and are subject to ATP $\left(P_{2}\right.$ receptor-mediated) control, which makes ATP a major trans-cellular signal in the brain. Albeit the possible role of ATP and $\mathrm{P}_{2}$ receptors in the control of epilepsy still remains unexplored, the ATPergic system is used as an extracellular signalling system by different sub-cellular compartments known to be affected upon seizure activity. Thus, both neurons (pre- and post-synaptically) as well as astrocytes and microglia can release ATP as a signalling molecule. Furthermore, all these compartments are equipped with ATP $\left(\mathrm{P}_{2}\right.$ receptors $)$, both ionotropic $\left(\mathrm{P}_{2 \mathrm{X}}\right)$ and metabotropic $\left(\mathrm{P}_{2 \mathrm{Y}}\right)$. Overall, ATP can act as a neurotransmitter (released pre-synaptically and acting post-synaptically), as a neuromodulator (released pre-, post and/or non-synaptically and acting pre-synaptically), as a gliotransmitter (released from astrocytes and acting on neurons or released from astrocytes acting autocrinally to sustain calcium wave propagation), as a neuron-glia messenger (released pre- and/or post-synaptically from neurons and acting on astrocytes, or vice-versa) and as an inflammatory mediator (released from microglia and/or astrocytes and acting on both glia cells). Since accumulating evidence supports that ATP acts as a danger signal, future work should address if and how ATP acting through P2 receptors might control seizure activity and associated neurodegeneration.

expression and density of $\mathrm{P}_{2} \mathrm{R}$ [292-294]. A recent elegant review hypothesised that ATP could play a key role in the control of epilepsy through its key control of astrocytic calcium waves [295]. A role for ATP in the modified activation state of microglia cells upon status epilepticus was also recently proposed [294]. Here, it will just be added that the $\mathrm{ATP} / \mathrm{P}_{2} \mathrm{R}$ system may also directly modify neuronal function. Since the ATP $/ \mathrm{P}_{2} \mathrm{R}$ system seems to be more relevant for the control of frequency-induced plastic changes of synaptic efficiency rather than to sustain basal synaptic transmission [296-300], it is possible that the ATP/ $\mathrm{P}_{2} \mathrm{R}$ system may be particularly involved in the control of ripples of high frequency firing characteristic of paroxysmal activity. Interestingly, it has been reported that the direct administration of ATP analogues into the piriform cortex triggers a generalised seizure activity [301]. Furthermore, the ATP/ $\mathrm{P}_{2} \mathrm{R}$ system seems to be of particular importance to control synaptic transmission in more extreme conditions, such as upon $\mathrm{pH}$ drops [302], which are also characteristic of seizure activity. Thus, there are multiple mechanisms to sustain a possible role for the $\mathrm{ATP} / \mathrm{P}_{2} \mathrm{R}$ system in the control of epilepsy. It is hoped that future studies will directly test the impact of $\mathrm{P}_{2} \mathrm{R}$ antagonists on the induction, propagation and consequences of seizure activity.

\section{CONCLUDING REMARKS}

Several take home messages, some more speculative than others, emerge from this brief overview of the putative role of purines in the control of seizure activity and resulting neurodegeneration:

1-First, $A_{1} R$ still emerge as the most efficacious purinergic modulation system to control seizure activity. However, it is becoming increasingly clear that the anti-epileptic role of $A_{1} R$ is probably operated through non-synaptic mechanisms: it may involve the ability of $A_{1} R$ to implement a state of lower susceptibility to insults (pre-conditioning) through their ability to control primary metabolism (see Fig. 4).

2-In this respect, dysfunction of astrocytes may be a crucial precipitating event determining the emergence of epilepsy; in fact, astrocytes play a crucial and predominant role 
in brain energetics and in the integrative ability of $\mathrm{A}_{1} \mathrm{R}$ to curtail excessive activity of brain circuits; thus, their disruption would blunt the gate-keeper role of the $\mathrm{A}_{1} \mathrm{R}$ neuromodulation system (see Fig. 5).

3-The accumulating evidence that $\mathrm{A}_{2 \mathrm{~A}} \mathrm{R}$ are up-regulated in animal models of epilepsy and that the blockade of $A_{2 A} R$ prevents seizure activity and the resulting neurodegeneration, prompts a novel key concept: adenosine can no longer be considered an anti-epileptic agent, since it can also contribute to worsen this conditions through $\mathrm{A}_{2 \mathrm{~A}} \mathrm{R}$-mediated actions (see Fig. 6).

4-Finally, increased awareness is required to consider the $\mathrm{ATP} / \mathrm{P}_{2} \mathrm{R}$ system as another possible major player in the control of seizure activity and epilepsy; in fact, ATP is increasingly recognised as a danger signal in the central nervous system and its role in the control of epilepsy is still unexplored.

This emerging scenario of multiple purinergic systems controlling seizure activity and epilepsy-related neurodegeneration unveils the need for future research to pinpoint the relative roles of $A_{1} R, A_{2 A} R$ and $P_{2} R$. Particular care should be devoted to the understanding of: 1) different timings of action; 2) different roles in the continuum between seizure initiation, its propagation, epileptogenesis and neurodegeneration. If this is achieved, then one may hope to design combined therapeutic strategies targeting the different arms of the purinergic system to effectively control different features associated with epilepsy.

\section{ABBREVIATIONS}

\begin{tabular}{|c|c|c|}
\hline $\mathrm{A}_{1} \mathrm{R}$ & $=$ & adenosine $A_{1}$ receptor \\
\hline $\mathrm{A}_{2 \mathrm{~A}} \mathrm{R}$ & $=$ & adenosine $A_{2 A}$ receptor \\
\hline $\mathrm{A} \beta_{1-42}$ & $=$ & $\beta$-amyloid $1-42$ peptide \\
\hline ADA & $=$ & adenosine deaminase \\
\hline ADK & $=$ & adenosine kinase \\
\hline AdoT & $=$ & adenosine transporters \\
\hline AHP & $=$ & after-hyperpolarising potential \\
\hline AMPK & $=$ & AMP kinase \\
\hline eNPP & $=$ & ecto-nucleotides pyro-phosphatases \\
\hline ENT 1 & $=$ & $\begin{array}{l}\text { equilibrative nucleoside transporters } \\
\text { type } 1\end{array}$ \\
\hline eNTPDase & $=$ & $\begin{array}{l}\text { ecto-nucleoside tri- } \begin{array}{l}- \\
\text { phosphatases }\end{array}\end{array}$ \\
\hline $\mathrm{K}_{\mathrm{ATP}}$ & $=$ & ATP-sensitive potassium channels \\
\hline LTP & $=$ & long term potentiation \\
\hline MAPK & $=$ & microtubule-associated protein kinases \\
\hline NMDA & $=$ & N-methyl-D-aspartate \\
\hline $\mathrm{P}_{2} \mathrm{R}$ & $=$ & $\mathrm{P}_{2}$ receptors \\
\hline PKC & $=$ & protein kinase $\mathrm{C}$ \\
\hline $\mathrm{SAH}$ & $=$ & S-adenosylhomocysteine \\
\hline SAM & $=$ & S-adenosylmethionine \\
\hline
\end{tabular}

\section{REFERENCES}

[1] Engel J, Pedley TA, Aicardi J, Dichter MA, Moshe S, Eds. Epilepsy: a comprehensive textbook. New York: Lippincott Williams \& Wilkins 2007

[2] Pugliatti M, Beghi E, Forsgren L, Ekman M, Sobocki P. Estimating the cost of epilepsy in Europe: a review with economic modeling. Epilepsia 2007; 48: 2224-33.

[3] Sperling MR, O'Connor MJ. Auras and subclinical seizures: characteristics and prognostic significance. Ann Neurol 2001; 28: 3208.

[4] Ben-Ari Y. Seizures beget seizures: the quest for GABA as a key player. Crit Rev Neurobiol 2006; 18: 135-44.

[5] Shorvon SD, Perucca E, Engel J, Jr, Eds. The treatment of epilepsy, London: Wiley Blackwell 2009.

[6] Shorvon SD. Drug treatment of epilepsy in the century of the ILAE: the first 50 years, 1909-1958. Epilepsia 2009; 50(Suppl 3): 69-92.

[7] Rogawski MA, Löscher W. The neurobiology of antiepileptic drugs. Nat Rev Neurosci 2004; 5: 553-64.

[8] Meldrum BS, Rogawski MA. Molecular targets for antiepileptic drug development. Neurotherapeutics 2007; 4: 18-61.

[9] Heinemann U, Kann O, Remy S, Beck H. Novel mechanisms underlying drug resistance in temporal lobe epilepsy. Adv Neurol 2006; 97:85-95.

[10] Haydon PG, Carmignoto G. Astrocyte control of synaptic transmission and neurovascular coupling. Physiol Rev 2006; 86: 1009-31.

[11] Fellin T, Halassa MM, Terunuma M, et al. Endogenous nonneuronal modulators of synaptic transmission control cortical slow oscillations in vivo. Proc Natl Acad Sci USA 2009; 106: 15037-42.

[12] Fellin T, D'Ascenzo M, Haydon PG. Astrocytes control neuronal excitability in the nucleus accumbens. ScientificWorldJournal 2007; 7: 89-97.

[13] Halassa MM, Fellin T, Haydon PG. The tripartite synapse: roles for gliotransmission in health and disease. Trends Mol Med 2007; 13: 54-63.

[14] Bushong EA, Martone ME, Jones YZ, Ellisman MH. Protoplasmic astrocytes in CA1 stratum radiatum occupy separate anatomical domains. J Neurosci 2002; 22: 183-92.

[15] Seifert G, Carmignoto G, Steinhäuser C. Astrocyte dysfunction in epilepsy. Brain Res Rev 2010; 63: 212-21.

[16] Jabs R, Seifert G, Steinhäuser C. Astrocytic function and its alteration in the epileptic brain. Epilepsia 2008; 49(Suppl 2): 3-12.

[17] Wetherington J, Serrano G, Dingledine R. Astrocytes in the epileptic brain. Neuron 2008; 58: 168-78.

[18] Oberheim NA, Tian GF, Han X, et al. Loss of astrocytic domain organization in the epileptic brain. J Neurosci 2008; 28: 3264-76.

[19] Boison D. The adenosine kinase hypothesis of epileptogenesis. Prog Neurobiol 2008; 84: 249-62.

[20] Sokoloff L. The brain as a chemical machine. Prog Brain Res 1992; 94: 19-33.

[21] Stafstrom CE, Roopra A, Sutula TP. Seizure suppression via glycolysis inhibition with 2-deoxy-D-glucose (2DG). Epilepsia 2008; 49(Suppl 8): 97-100.

[22] Van Paesschen W, Dupont P, Sunaert S, Goffin K, Van Laere K. The use of SPECT and PET in routine clinical practice in epilepsy. Curr Opin Neurol 2007; 20: 194-202.

[23] Pan JW, Williamson A, Cavus I, et al. Neurometabolism in human epilepsy. Epilepsia 2008; 49(Suppl 3): 31-41.

[24] Cloix JF, Hévor T. Epilepsy, regulation of brain energy metabolism and neurotransmission. Curr Med Chem 2009; 16: 841-53.

[25] Wilder RM. The effects of ketonemia on the course of epilepsy. Mayo Clin Proc 1921; 2: 307-8.

[26] Vamecq J, Vallée L, Lesage F, Gressens P, Stables JP. Antiepileptic popular ketogenic diet: emerging twists in an ancient story. Prog Neurobiol 2005; 75: 1-28.

[27] Hartman AL, Gasior M, Vining EP, Rogawski MA. The neuropharmacology of the ketogenic diet. Pediatr Neurol 2007; 36: 28192.

[28] Masino SA, Geiger JD. Are purines mediators of the anticonvulsant/neuroprotective effects of ketogenic diets? Trends Neurosci 2008; 31: 273-8. 
[29] Neal EG, Chaffe H, Schwartz RH, et al. The ketogenic diet for the treatment of childhood epilepsy: a randomised controlled trial. Lancet Neurol 2008; 7: 500-6.

[30] Freeman JM, Kossoff EH, Hartman AL. The ketogenic diet: one decade later. Pediatrics 2007; 119: 535-43.

[31] Hauser WA, Lee JR. Do seizures beget seizures? Prog Brain Res 2002; 135: 215-9.

[32] Yogeeswari P, Ragavendran JV, Thirumurugan R, Saxena A, Sriram D. Ion channels as important targets for antiepileptic drug design. Curr Drug Targets 2004; 5: 589-602.

[33] Morimoto K, Fahnestock M, Racine RJ. Kindling and status epilepticus models of epilepsy: rewiring the brain. Prog Neurobiol 2004; 73: $1-60$.

[34] Naegele JR. Neuroprotective strategies to avert seizure-induced neurodegeneration in epilepsy. Epilepsia 2007; 48(Suppl 2): 107 17.

[35] Sutula T. Antiepileptic drugs to prevent neural degeneration associated with epilepsy: assessing the prospects for neuroprotection. Epilepsy Res 2002; 50: 125-9.

[36] Henshall DC, Simon RP. Epilepsy and apoptosis pathways. J Cereb Blood Flow Metab 2005; 25: 1557-72.

[37] Drury AN, Szent-Gyorgyi A. The physiological activity of adenine compounds with special reference to their action upon the mammalian heart. J Physiol 1929; 68: 213-37.

[38] Sattin A, Rall TW. The effect of adenosine and adenine nucleotides on the cyclic adenosine 3',5'-phosphate content of guinea pig cerebral cortex slices. Mol Pharmacol 1970; 6: 13-23.

[39] Daly JW, Bruns RF, Snyder SH. Adenosine receptors in the central nervous system: relationship to the central actions of methylxanthines. Life Sci 1981; 28: 2083-97.

[40] Fredholm BB, Chen JF, Cunha RA, Svenningsson P, Vaugeois JM. Adenosine and brain function. Int Rev Neurobiol 2005; 63: 191270.

[41] Fredholm BB, IJzerman AP, Jacobson KA, Klotz KN, Linden J. International Union of Pharmacology. XXV: Nomenclature and classification of adenosine receptors. Pharmacol Rev 2001; 53: 527-52.

[42] Fastbom J, Pazos A, Palacios JM. The distribution of adenosine A1 receptors and 5'-nucleotidase in the brain of some commonly used experimental animals. Neuroscience 1997; 22: 813-26.

[43] Tetzlaff W, Schubert P, Kreutzberg GW. Synaptic and extrasynaptic localization of adenosine binding sites in the rat hippocampus. Neuroscience 1987; 21: 869-75.

[44] Rebola N, Pinheiro PC, Oliveira CR, Malva JO, Cunha RA. Subcellular localization of adenosine A1 receptors in nerve terminals and synapses of the rat hippocampus. Brain Res 2003; 987: 49-58.

[45] Lambert NA, Teyler TJ. Adenosine depresses excitatory but not fast inhibitory synaptic transmission in area CA1 of the rat hippocampus. Neurosci Lett 1991; 122: 50-2.

[46] Yoon KW, Rothman SM. Adenosine inhibits excitatory but not inhibitory synaptic transmission in the hippocampus. J Neurosci 1991; 11: 1375-80.

[47] Yang K, Fujita T, Kumamoto E. Adenosine inhibits GABAergic and glycinergic transmission in adult rat substantia gelatinosa neurons. J Neurophysiol 2004; 92: 2867-77.

[48] Yum DS, Cho JH, Choi IS, et al. Adenosine A1 receptors inhibit GABAergic transmission in rat tuberomammillary nucleus neurons. J Neurochem 2008; 106: 361-71.

[49] Courjaret R, Tröger M, Deitmer JW. Suppression of GABA input by $\mathrm{A} 1$ adenosine receptor activation in rat cerebellar granule cells. Neuroscience 2009; 162: 946-58.

[50] Abu-Shaweesh JM. Activation of central adenosine A2A receptors enhances superior laryngeal nerve stimulation-induced apnea in piglets via a GABAergic pathway. J Appl Physiol 2007; 103: 120511.

[51] Wu LG, Saggau P. Adenosine inhibits evoked synaptic transmission primarily by reducing presynaptic calcium influx in area CA1 of hippocampus. Neuron 1994; 12: 1139-48.

[52] Ambrósio AF, Malva JO, Carvalho AP, Carvalho CM. Modulation of $\mathrm{Ca} 2+$ channels by activation of adenosine A1 receptors in rat striatal glutamatergic nerve terminals. Neurosci Lett 1996; 220: 163-6.
[53] Klishin A, Lozovaya N, Krishtal O. A1 adenosine receptors differentially regulate the N-methyl-d-aspartate and non-N-methyl-daspartate receptor-mediated components of hippocampal excitatory postsynaptic current in a $\mathrm{Ca}^{2+} / \mathrm{Mg}^{2+}$-dependent manner. Neuroscience $1995 ; 65 ; 947-53$.

[54] de Mendonça A, Sebastião AM, Ribeiro JA. Inhibition of NMDA receptor-mediated currents in isolated rat hippocampal neurones by adenosine A1 receptor activation. Neuroreport 1995; 6: 1097-100.

[55] Greene RW, Haas HL. The electrophysiology of adenosine in the mammalian central nervous system. Prog Neurobiol 1991; 36: 32941.

[56] Haas HL, Greene RW. Endogenous adenosine inhibits hippocampal CA1 neurones: further evidence from extra- and intracellular recording. Naunyn Schmiedebergs Arch Pharmacol 1988; 337: 561-5.

[57] Dunwiddie TV. Endogenously released adenosine regulates excitability in the in vitro hippocampus. Epilepsia 1980; 21: 541-8.

[58] Cunha RA, Sebastião AM, Ribeiro JA. Inhibition by ATP of hippocampal synaptic transmission requires localized extracellular catabolism by ecto-nucleotidases into adenosine and channeling to adenosine A1 receptors. J Neurosci 1998; 18: 1987-95.

[59] Mitchell JB, Lupica CR, Dunwiddie TV. Activity-dependent release of endogenous adenosine modulates synaptic responses in the rat hippocampus. J Neurosci 1993; 13: 3439-47.

[60] Manzoni OJ, Manabe T, Nicoll RA. Release of adenosine by activation of NMDA receptors in the hippocampus. Science 1994; 265 : 2098-101.

[61] Serrano A, Haddjeri N, Lacaille JC, Robitaille R. GABAergic network activation of glial cells underlies hippocampal heterosynaptic depression. J Neurosci 2006; 26: 5370-82.

[62] Pascual O, Casper KB, Kubera C, et al. Astrocytic purinergic signaling coordinates synaptic networks. Science 2005; 310: 113-6.

[63] Haberg A, Qu H, Haraldseth O, Unsgard G, Sonnewald U. In vivo effects of adenosine A1 receptor agonist and antagonist on neuronal and astrocytic intermediary metabolism studied with ex vivo 13C NMR spectroscopy. J Neurochem 2000; 74: 327-33.

[64] Heurteaux C, Lauritzen I, Widmann C. Essential role of adenosine, adenosine A1 receptors, and ATP-sensitive $\mathrm{K}+$ channels in cerebral ischemic preconditioning. Proc Natl Acad Sci USA 1995; 92: 4666-70.

[65] van Calker D, Biber K. The role of glial adenosine receptors in neural resilience and the neurobiology of mood disorders. Neurochem Res 2005; 30: 1205-17.

[66] Gebicke-Haerter PJ, ChristoVel F, Timmer J, Northo VH, Berger M, Van Calker D. Both adenosine A1- and A2-receptors are required to stimulate microglial proliferation. Neurochem Int 1996; 29: 37-42.

[67] Othman T, Yan H, Rivkees SA. Oligodendrocytes express functional A1 adenosine receptors that stimulate cellular migration. Glia 2003; 44: 166-72.

[68] Daré E, Schulte G, Karovic O, Hammarberg C, Fredholm BB. Modulation of glial cell functions by adenosine receptors. Physiol Behav 2007; 92: 15-20.

[69] Svenningsson P, Le Moine C, Fisone G, Fredholm BB. Distribution, biochemistry and function of striatal adenosine A2A receptors. Prog Neurobiol 1999; 59: 355-96.

[70] Cunha RA, Johansson B, van der Ploeg I, Sebastião AM, Ribeiro JA, Fredholm BB. Evidence for functionally important adenosine A2a receptors in the rat hippocampus. Brain Res 1994; 649: 20816.

[71] Johansson B, Fredholm BB. Further characterization of the binding of the adenosine receptor agonist [3H]CGS 21680 to rat brain using autoradiography. Neuropharmacology 1995; 34: 393-403.

[72] Rosin DL, Robeva A, Woodard RL, Guyenet PG, Linden J. Immunohistochemical localization of adenosine $\mathrm{A} 2 \mathrm{~A}$ receptors in the rat central nervous system. J Comp Neurol 1998; 401: 163-86.

[73] Rebola N, Canas PM, Oliveira CR, Cunha RA. Different synaptic and subsynaptic localization of adenosine A2A receptors in the hippocampus and striatum of the rat. Neuroscience 2005; 132: 893903.

[74] Rodrigues RJ, Alfaro TM, Rebola N, Oliveira CR, Cunha RA. Colocalization and functional interaction between adenosine $\mathrm{A} 2 \mathrm{~A}$ and 
metabotropic group 5 receptors in glutamatergic nerve terminals of the rat striatum. J Neurochem 2005; 92: 433-41.

[75] Marchi M, Raiteri L, Risso F, Vallarino A, Bonfanti A, Monopoli A, Ongini E, Raiteri M. Effects of adenosine A1 and A2A receptor activation on the evoked release of glutamate from rat cerebrocortical synaptosomes. Br J Pharmacol 2002; 136: 434-40.

[76] Lopes LV, Cunha RA, Ribeiro JA. Cross talk between A1 and A2A adenosine receptors in the hippocampus and cortex of young adult and old rats. J Neurophysiol 1999; 82: 3196-203.

[77] Ciruela F, Casadó V, Rodrigues RJ, et al. Presynaptic control of striatal glutamatergic neurotransmission by adenosine $\mathrm{A} 1-\mathrm{A} 2 \mathrm{~A}$ receptor heteromers. J Neurosci 2006; 26: 2080-7.

[78] Rebola N, Lujan R, Cunha RA, Mulle C. Long-term potentiation of NMDA-EPSCs at hippocampal mossy fiber synapses: an essential role for adenosine A2A receptors. Neuron 2008; 57: 121-34.

[79] Wirkner K, Gerevich Z, Krause T, et al. Adenosine A2A receptorinduced inhibition of NMDA and GABAA receptor-mediated synaptic currents in a subpopulation of rat striatal neurons. Neuropharmacology 2004; 46: 994-1007.

[80] Li H, Henry JL. Adenosine A2 receptor mediation of pre- and postsynaptic excitatory effects of adenosine in rat hippocampus in vitro. Eur J Pharmacol 1998; 347: 173-82.

[81] Ponzio TA, Wang YF, Hatton GI. Activation of adenosine A2A receptors alters postsynaptic currents and depolarizes neurons of the supraoptic nucleus. Am J Physiol 2006; 291: R359-66.

[82] Lupica CR, Cass WA, Zahniser NR, Dunwiddie TV. Effects of the selective adenosine A2 receptor agonist CGS 21680 on in vitro electrophysiology, cAMP formation and dopamine release in rat hippocampus and striatum. J Pharmacol Exp Ther 1990; 252: 113441.

[83] Cunha RA, Constantino MD, Ribeiro JA. ZM241385 is an antagonist of the facilitatory responses produced by the A2A adenosine receptor agonists CGS21680 and HENECA in the rat hippocampus. Br J Pharmacol 1997; 122: 1279-84.

[84] D'Alcantara P, Ledent C, Swillens S, Schiffmann SN. Inactivation of adenosine $\mathrm{A} 2 \mathrm{~A}$ receptors impairs long term potentiation in the accumbens nucleus without altering basal synaptic transmission. Neuroscience 2001; 107: 455-64.

[85] Cunha RA. Different cellular sources and different roles of adenosine: A1 receptor-mediated inhibition through astrocytic-driven volume transmission and synapse-restricted $\mathrm{A} 2 \mathrm{~A}$ receptormediated facilitation of plasticity. Neurochem Int 2008; 52: 65-72.

[86] Sebastião AM, Ribeiro JA. Fine-tuning neuromodulation by adenosine. Trends Pharmacol Sci 2000; 21: 341-6.

[87] Sebastião AM, Ribeiro JA. Triggering neurotrophic factor actions through adenosine $\mathrm{A} 2 \mathrm{~A}$ receptor activation: implications for neuroprotection. Br J Pharmacol 2009; 158: 15-22.

[88] Sebastião AM, Macedo MP, Ribeiro JA. Tonic activation of A2A adenosine receptors unmasks, and of A1 receptors prevents, a facilitatory action of calcitonin gene-related peptide in the rat hippocampus. Br J Pharmacol 2000; 129: 374-80.

[89] Cunha-Reis D, Fontinha BM, Ribeiro JA, Sebastião AM. Tonic adenosine $\mathrm{A} 1$ and $\mathrm{A} 2 \mathrm{~A}$ receptor activation is required for the excitatory action of VIP on synaptic transmission in the CA1 area of the hippocampus. Neuropharmacology 2007; 52: 313-20.

[90] Tebano MT, Martire A, Chiodi V, et al. Adenosine A2A receptors enable the synaptic effects of cannabinoid CB1 receptors in the rodent striatum. J Neurochem 2009; 110: 1921-30.

[91] Lopes LV, Cunha RA, Ribeiro JA. ZM 241385, an adenosine A2A receptor antagonist, inhibits hippocampal A1 receptor responses. Eur J Pharmacol 1999; 383: 395-8.

[92] Hammer J, Qu H, Haberg A, Sonnewald U. In vivo effects of adenosine A2 receptor agonist and antagonist on neuronal and astrocytic intermediary metabolism studied with ex vivo $13 \mathrm{C}$ MR spectroscopy. J Neurochem 2002; 79: 885-92.

[93] Chen JF, Pedata F. Modulation of ischemic brain injury and neuroinflammation by adenosine A2A receptors. Curr Pharm Des 2008; 14: 1490-9.

[94] Nishizaki T, Nagai K, Nomura T, et al. A new neuromodulatory pathway with a glial contribution mediated via A2a adenosine receptors. Glia 2001; 39: 133-47.
[95] Pankratov Y, Lalo U, Verkhratsky A, North RA. Vesicular release of ATP at central synapses. Pflugers Arch 2006; 452: 589-97.

[96] Pangrsic T, Potokar M, Stenovec M, et al. Exocytotic release of ATP from cultured astrocytes. J Biol Chem 2007; 282: 28749-58.

[97] Zhang Z, Chen G, Zhou W, et al. Regulated ATP release from astrocytes through lysosome exocytosis. Nat Cell Biol 2007; 9: 945-53.

[98] White TD, MacDonald WF. Neural release of ATP and adenosine. Ann N Y Acad Sci 1990; 603: 287-99.

[99] Cunha RA. Regulation of the ecto-nucleotidase pathway in rat hippocampal nerve terminals. Neurochem Res 2001; 26: 979-91.

[100] Zimmermann H. Ectonucleotidases in the nervous system. Novartis Found Symp 2006; 276: 113-28.

[101] Young JD, Yao SY, Sun L, Cass CE, Baldwin SA. Human equilibrative nucleoside transporter (ENT) family of nucleoside and nucleobase transporter proteins. Xenobiotica 2008; 38: 995-1021.

[102] Zimmermann H, Braun N, Kegel B, Heine P. New insights into molecular structure and function of ectonucleotidases in the nervous system. Neurochem Int 1998; 32: 421-5.

[103] Gu JG, Foga IO, Parkinson FE, Geiger JD. Involvement of bidirectional adenosine transporters in the release of $\mathrm{L}-[3 \mathrm{H}]$ adenosine from rat brain synaptosomal preparations. J Neurochem 1995; 64: 2105-10.

[104] Cunha RA. Adenosine as a neuromodulator and as a homeostatic regulator in the nervous system: different roles, different sources and different receptors. Neurochem Int 2001; 38: 107-25.

[105] Terrian DM, Hernandez PG, Rea MA, Peters RI. ATP release, adenosine formation, and modulation of dynorphin and glutamic acid release by adenosine analogues in rat hippocampal mossy fiber synaptosomes. J Neurochem 1989; 53: 1390-9.

[106] Cunha RA, Almeida T, Ribeiro JA. Modification by arachidonic acid of extracellular adenosine metabolism and neuromodulatory action in the rat hippocampus. J Biol Chem 2000; 275: 37572-81.

[107] Cunha RA, Almeida T, Ribeiro JA. Parallel modification of adenosine extracellular metabolism and modulatory action in the hippocampus of aged rats. J Neurochem 2001; 76: 372-82.

[108] Pankratov Y, Lalo U, Verkhratsky A, North RA. Quantal release of ATP in mouse cortex. J Gen Physiol 2007; 129: 257-65.

[109] Wieraszko A, Goldsmith G, Seyfried TN. Stimulation-dependent release of adenosine triphosphate from hippocampal slices. Brain Res 1989; 485: 244-50.

[110] Cunha RA, Vizi ES, Sebastião AM, Ribeiro JA. Preferential release of ATP and its extracellular catabolism as a source of adenosine upon high- but not low-frequency stimulation of rat hippocampal slices. J Neurochem 1996; 67: 2180-7.

[111] Latini S, Pedata F. Adenosine in the central nervous system: release mechanisms and extracellular concentrations. J Neurochem 2001; 79: 463-84.

[112] Doolette DJ. Mechanism of adenosine accumulation in the hippocampal slice during energy deprivation. Neurochem Int 1997; 30: 211-23.

[113] Fredholm BB, Lindstrom K, Wallman-Johansson A. Propentofylline and other adenosine transport inhibitors increase the efflux of adenosine following electrical or metabolic stimulation of rat hippocampal slices. J Neurochem 1994; 62: 563-73.

[114] Frenguelli BG, Llaudet E, Dale N. High-resolution real-time recording with microelectrode biosensors reveals novel aspects of adenosine release during hypoxia in rat hippocampal slices. J Neurochem 2003; 86: 1506-15.

[115] Dunwiddie TV, Diao L, Proctor WR. Adenine nucleotides undergo rapid, quantitative conversion to adenosine in the extracellular space in rat hippocampus. J Neurosci 1997; 17: 7673-82.

[116] Dunwiddie TV, Diao L. Regulation of extracellular adenosine in rat hippocampal slices is temperature dependent: role of adenosine transporters. Neuroscience 2000; 95: 81-8.

[117] Narimatsu E, Aoki M. Transient depression of excitatory synaptic transmission induced by adenosine uptake inhibition in rat hippocampal slices. Brain Res 2000; 862: 284-7.

[118] Chen J, Rinaldo L, Lim SJ, Young H, Messing RO, Choi DS. The type 1 equilibrative nucleoside transporter regulates anxiety-like behavior in mice. Genes Brain Behav 2007; 6: 776-83. 
[119] Ceballos G, Tuttle JB, Rubio R. Differential distribution of purine metabolizing enzymes between glia and neurons. J Neurochem 1994; 62: 1144-53.

[120] Parkinson FE, Sinclair CJ, Othman T, Haughey NJ, Geiger JD. Differences between rat primary cortical neurons and astrocytes in purine release evoked by ischemic conditions. Neuropharmacology 2002; 43: 836-46.

[121] Moriwaki Y, Yamamoto T, Higashino K. Enzymes involved in purine metabolism--a review of histochemical localization and functional implications. Histol Histopathol 1999; 14: 1321-40.

[122] Lloyd HHE, Lindstrom K, Fredholm BB. Intracellular formation and release of adenosine from rat hippocampal slices evoked by electrical stimulation or energy depletion. Neurochem Int 1993; 23: 173-85.

[123] Etherington LA, Patterson GE, Meechan L, et al. Astrocytic adenosine kinase regulates basal synaptic adenosine levels and seizure activity but not activity-dependent adenosine release in the hippocampus. Neuropharmacology 2009; 56: 429-37.

[124] Brundege JM, Dunwiddie TV. Metabolic regulation of endogenous adenosine release from single neurons. Neuroreport 1998; 9: 300711.

[125] Zhu PJ, Krnjević K. Endogenous adenosine deaminase does not modulate synaptic transmission in rat hippocampal slices under normoxic or hypoxic conditions. Neuroscience 1994; 63: 489-97.

[126] Li T, Ren G, Lusardi T, et al. Adenosine kinase is a target for the prediction and prevention of epileptogenesis in mice. J Clin Invest 2008; 118: 571-82.

[127] Fedele DE, Gouder N, Güttinger M, et al. Astrogliosis in epilepsy leads to overexpression of adenosine kinase, resulting in seizure aggravation. Brain 2005;128: 2383-95.

[128] Studer FE, Fedele DE, Marowsky A, et al. Shift of adenosine kinase expression from neurons to astrocytes during postnatal development suggests dual functionality of the enzyme. Neuroscience 2006; 142: 125-37.

[129] Schousboe A, Sarup A, Bak LK, Waagepetersen HS, Larsson OM. Role of astrocytic transport processes in glutamatergic and GABAergic neurotransmission. Neurochem Int 2004; 45: 521-7.

[130] Rusakov DA, Harrison E, Stewart MG. Synapses in the hippocampus occupy only $1-2 \%$ of cell membranes and are spaced less than half-micron apart: a quantitative ultrastructural analysis with discussion of physiological implications. Neuropharmacology 1998; 37: 513-21.

[131] Rebola N, Rodrigues RJ, Lopes LV, Richardson PJ, Oliveira CR, Cunha RA. Adenosine A1 and A2A receptors are co-expressed in pyramidal neurons and co-localized in glutamatergic nerve terminals of the rat hippocampus. Neuroscience 2005;133: 79-83.

[132] Cunha RA, Correia-de-Sá P, Sebastião AM, Ribeiro JA. Preferential activation of excitatory adenosine receptors at rat hippocampal and neuromuscular synapses by adenosine formed from released adenine nucleotides. Br J Pharmacol 1996; 119: 253-60.

[133] Pinto-Duarte A, Coelho JE, Cunha RA, Ribeiro JA, Sebastião AM. Adenosine A2A receptors control the extracellular levels of adenosine through modulation of nucleoside transporters activity in the rat hippocampus. J Neurochem 2005; 93: 595-604.

[134] de Mendonça A, Sebastião AM, Ribeiro JA. Adenosine: does it have a neuroprotective role after all? Brain Res Rev 2000; 33: 25874.

[135] Dunwiddie TV. Adenosine and suppression of seizures. In: Delgado-Escuta AV, Wilson WA, Olsen RW, Porter RJ, Eds. Jasper's basic mechanisms of the epilepsies. $3^{\text {rd }}$ ed. Advances in neurology. Philadelphia: Lippincott Williams \& Wilkins 1999; Vol. 79.

[136] Malva JO, Silva AP, Cunha RA. Presynaptic modulation controlling neuronal excitability and epileptogenesis: role of kainate, adenosine and neuropeptide Y receptors. Neurochem Res 2003; 28 : 1499-513.

[137] Dragunow M. Purinergic mechanisms in epilepsy. Prog Neurobiol 1988; 31: 85-108.

[138] Berman RF, Fredholm BB, Aden U, O'Connor WT. Evidence for increased dorsal hippocampal adenosine release and metabolism during pharmacologically induced seizures in rats. Brain Res 2000; 872: 44-53.
[139] During MJ, Spencer DD. Adenosine: a potential mediator of seizure arrest and postictal refractoriness. Ann Neurol 1992; 32: 61824.

[140] Fedele DE, Li T, Lan JQ, Fredholm BB, Boison D. Adenosine A1 receptors are crucial in keeping an epileptic focus localized. Exp Neurol 2006; 200: 184-90.

[141] Kochanek PM, Vagni VA, Janesko KL, et al. Adenosine A1 receptor knockout mice develop lethal status epilepticus after experimental traumatic brain injury. J Cereb Blood Flow Metab 2006; 26 : 565-75.

[142] Li T, Steinbeck JA, Lusardi T, et al. Suppression of kindling epileptogenesis by adenosine releasing stem cell-derived brain implants. Brain 2007; 130: 1276-88.

[143] Rebola N, Coelho JE, Costenla AR, et al. Decrease of adenosine A1 receptor density and of adenosine neuromodulation in the hippocampus of kindled rats. Eur J Neurosci 2003; 18: 820-8.

[144] Ekonomou A, Sperk G, Kostopoulos G, Angelatou F. Reduction of A1 adenosine receptors in rat hippocampus after kainic acidinduced limbic seizures. Neurosci Lett 2000; 284: 49-52.

[145] Glass M, Faull RL, Bullock JY, et al. Loss of A1 adenosine receptors in human temporal lobe epilepsy. Brain Res 1996; 710: 56-68.

[146] Ochiishi T, Takita M, Ikemoto M, Nakata H, Suzuki SS. Immunohistochemical analysis on the role of adenosine A1 receptors in epilepsy. Neuroreport 1999; 10: 3535-41.

[147] Gouder N, Fritschy JM, Boison D. Seizure suppression by adenosine A1 receptor activation in a mouse model of pharmacoresistant epilepsy. Epilepsia 2003; 44: 877-85.

[148] Khan GM, Smolders I, Ebinger G, Michotte Y. Anticonvulsant effect and neurotransmitter modulation of focal and systemic 2chloroadenosine against the development of pilocarpine-induced seizures. Neuropharmacology 2000; 39: 2418-32.

[149] Khan GM, Smolders I, Ebinger G, Michotte Y. 2-Chloro-N(6)cyclopentyladenosine-elicited attenuation of evoked glutamate release is not sufficient to give complete protection against pilocarpine-induced seizures in rats. Neuropharmacology 2001; 40: 657-67.

[150] Fredholm BB, Battig K, Holmen J, Nehlig A, Zvartau E. Actions of caffeine in the brain with special reference to factors that contribute to its widespread use. Pharmacol Rev 1999; 51: 83-153.

[151] Georgiev V, Johansson B, Fredholm BB. Long-term caffeine treatment leads to a decreased susceptibility to NMDA-induced clonic seizures in mice without changes in adenosine A1 receptor number. Brain Res 1993; 612: 271-7.

[152] Johansson B, Kuosmanen T, Fredholm BB. Long-term treatment with some methylxanthines decreases the susceptibility to bicuculline- and pentylenetetrazol-induced seizures in mice: relationship to c-fos expression and receptor binding. Eur J Neurosci 1996; 295: 147-54.

[153] Rigoulot MA, Leroy C, Koning E, Ferrandon A, Nehlig A. Prolonged low-dose caffeine exposure protects against hippocampal damage but not against the occurrence of epilepsy in the lithiumpilocarpine model in the rat. Epilepsia 2003; 44: 529-35.

[154] Duarte JMN, Carvalho RA, Cunha RA, Gruetter R. Caffeine consumption attenuates neurochemical modifications in the hippocampus of streptozotocin-induced diabetic rats. J Neurochem 2009: 111: 368-79.

[155] Johansson B, Georgiev V, Lindström K, Fredholm BB. A1 and $\mathrm{A} 2 \mathrm{~A}$ adenosine receptors and A1 mRNA in mouse brain: effect of long-term caffeine treatment. Brain Res 1997; 762: 153-64.

[156] Rebola N, Porciúncula LO, Lopes LV, Oliveira CR, Soares-da-Silva P, Cunha RA. Long-term effect of convulsive behavior on the density of adenosine $\mathrm{A} 1$ and $\mathrm{A} 2 \mathrm{~A}$ receptors in the rat cerebral cortex. Epilepsia 2005; 46(Suppl 5): 159-65.

[157] Boison D. Adenosine kinase, epilepsy and stroke: mechanisms and therapies. Trends Pharmacol Sci 2006; 27: 652-8.

[158] Stella L, Berrino L, Maione S, de Novellis V, Rossi F. Cardiovascular effects of adenosine and its analogs in anaesthetized rats. Life Sci 1993; 53: 755-63.

[159] Pan JW, Williamson A, Cavus I, et al. Neurometabolism in human epilepsy. Epilepsia 2008; 49(Suppl 3): 31-41.

[160] Nicotera P, Leist M, Manzo L. Neuronal cell death: a demise with different shapes. Trends Pharmacol Sci 1999; 20: 46-51. 
[161] Nicholls DG. Mitochondrial dysfunction and glutamate excitotoxicity studied in primary neuronal cultures. Curr Mol Med 2004; 4 : $149-77$.

[162] Gibson GE, Starkov A, Blass JP, Ratan RR, Beal MF. Cause and consequence: mitochondrial dysfunction initiates and propagates neuronal dysfunction, neuronal death and behavioral abnormalities in age-associated neurodegenerative diseases. Biochim Biophys Acta 2010; 1802: 122-34.

[163] Peart JN, Headrick JP. Adenosinergic cardioprotection: multiple receptors, multiple pathways. Pharmacol Ther 2007; 114: 208-21.

[164] Wendler CC, Amatya S, McClaskey C, Ghatpande S, Fredholm BB, Rivkees SA. A1 adenosine receptors play an essential role in protecting the embryo against hypoxia. Proc Natl Acad Sci USA 2007; 104: 9697-702.

[165] Joo JD, Kim M, Horst P, et al. Acute and delayed renal protection against renal ischemia and reperfusion injury with A1 adenosine receptors. Am J Physiol 2007; 293: F1847-57.

[166] Lee HT, Xu H, Nasr SH, Schnermann J, Emala CW. A1 adenosine receptor knockout mice exhibit increased renal injury following ischemia and reperfusion. Am J Physiol 2004; 286: F298-306.

[167] Kim J, Kim M, Song JH, Lee HT. Endogenous A1 adenosine receptors protect against hepatic ischemia reperfusion injury in mice. Liver Transpl 2008; 14: 845-54.

[168] Finegan BA, Lopaschuk GD, Gandhi M, Clanachan AS. Inhibition of glycolysis and enhanced mechanical function of working rat hearts as a result of adenosine A1 receptor stimulation during reperfusion following ischaemia. Br J Pharmacol 1996; 118: 35563.

[169] Fraser H, Lopaschuk GD, Clanachan AS. Cardioprotection by adenosine A1-receptor stimulation alters glycogen and glucose metabolism. Br J Pharmacol 199; 128: 197-205.

[170] Gao Z, Downey HF, Sun J, He M, Mallet RT. Adenosine receptor blockade enhances glycolysis in hypoperfused guinea-pig myocardium. Cardiovasc Res 1997; 33: 31-44.

[171] Wyatt DA, Edmunds MC, Rubio R, Berne RM, Lasley RD, Mentzer RM Jr. Adenosine stimulates glycolytic flux in isolated perfused rat hearts by A1-adenosine receptors. Am J Physiol 1989; 257: H1952-7.

[172] Blood AB, Hunter CJ, Power GG. Adenosine mediates decreased cerebral metabolic rate and increased cerebral blood flow during acute moderate hypoxia in the near-term fetal sheep. J Physiol 2003; 553: 935-45.

[173] Magistretti PJ, Hof PR, Martin JL. Adenosine stimulates glycogenolysis in mouse cerebral cortex: a possible coupling mechanism between neuronal activity and energy metabolism. J Neurosci 1986; 6: 2558-62.

[174] Canals S, Larrosa B, Pintor J, Mena MA, Herreras O. Metabolic challenge to glia activates an adenosine-mediated safety mechanism that promotes neuronal survival by delaying the onset of spreading depression waves. J Cereb Blood Flow Metab 2008; 28: 1835-44.

[175] Daval JL, Nicolas F. Non-selective effects of adenosine A1 receptor ligands on energy metabolism and macromolecular biosynthesis in cultured central neurons. Biochem Pharmacol 1998; 55: 141-9.

[176] Nehlig A, Daval JL, Boyet S. Effects of selective adenosine A1 and A2 receptor agonists and antagonists on local rates of energy metabolism in the rat brain. Eur J Pharmacol 1994; 258: 57-66.

[177] Sai K, Yang D, Yamamoto H, et al. A1 adenosine receptor signal and AMPK involving caspase-9/-3 activation are responsible for adenosine-induced RCR-1 astrocytoma cell death. Neurotoxicology 2006; 27: 458-67.

[178] Brust TB, Cayabyab FS, Zhou N, MacVicar BA. p38 mitogenactivated protein kinase contributes to adenosine A1 receptormediated synaptic depression in area CA1 of the rat hippocampus. J Neurosci 2006; 26: 12427-38.

[179] D'Alimonte I, Ballerini P, Nargi E, et al. Staurosporine-induced apoptosis in astrocytes is prevented by A1 adenosine receptor activation. Neurosci Lett 2007; 418: 66-71.

[180] Liang YC, Huang CC, Hsu KS. A role of p38 mitogen-activated protein kinase in adenosine A1 receptor-mediated synaptic depotentiation in area CA1 of the rat hippocampus. Mol Brain 2008; 1 : 13.
[181] Lasley RD, Keith BJ, Kristo G, Yoshimura Y, Mentzer RM Jr. Delayed adenosine A1 receptor preconditioning in rat myocardium is MAPK dependent but iNOS independent. Am J Physiol 2005; 289: H785-91.

[182] Miura T, Liu Y, Kita H, Ogawa T, Shimamoto K. Roles of mitochondrial ATP-sensitive $\mathrm{K}$ channels and $\mathrm{PKC}$ in anti-infarct tolerance afforded by adenosine A1 receptor activation. J Am Coll Cardiol 2000; 35: 238-45.

[183] Yoshida M, Nakakimura K, Cui YJ, Matsumoto M, Sakabe T. Adenosine A1 receptor antagonist and mitochondrial ATP-sensitive potassium channel blocker attenuate the tolerance to focal cerebral ischemia in rats. J Cereb Blood Flow Metab 2004; 24: 771-9.

[184] Baxter GF, Yellon DM. ATP-sensitive K+ channels mediate the delayed cardioprotective effect of adenosine A1 receptor activation. J Mol Cell Cardiol 1999; 31: 981-9.

[185] Ocaña M, Baeyens JM. Role of ATP-sensitive K+ channels in antinociception induced by R-PIA, an adenosine A1 receptor agonist. Naunyn Schmiedebergs Arch Pharmacol 1994; 350: 57-62.

[186] Kim E, Han J, Ho W, Earm YE. Modulation of ATP-sensitive K+ channels in rabbit ventricular myocytes by adenosine A1 receptor activation. Am J Physiol 1997; 272: H325-33.

[187] Spasić MR, Callaerts P, Norga KK. AMP-activated protein kinase (AMPK) molecular crossroad for metabolic control and survival of neurons. Neuroscientist 2009; 15: 309-16.

[188] Busija DW, Lacza Z, Rajapakse N, et al. Targeting mitochondrial ATP-sensitive potassium channels--a novel approach to neuroprotection. Brain Res Rev 2004; 46: 282-94.

[189] Mielke K, Herdegen T. JNK and p38 stress kinases--degenerative effectors of signal-transduction-cascades in the nervous system. Prog Neurobiol 2000; 61: 45-60.

[190] Dirnagl U, Becker K, Meisel A. Preconditioning and tolerance against cerebral ischaemia: from experimental strategies to clinical use. Lancet Neurol 2009; 8: 398-412.

[191] Leré C, El Bahh B, Le Gal La Salle G, Rougier A. A model of 'epileptic tolerance' for investigating neuroprotection, epileptic susceptibility and gene expression-related plastic changes. Brain Res Protoc 2002; 9: 49-56.

[192] Simon R, Henshall D, Stoehr S, Meller R. Endogenous mechanisms of neuroprotection. Epilepsia 2007; 48(Suppl 8): 72-3.

[193] Dirnagl U, Simon RP, Hallenbeck JM. Ischemic tolerance and endogenous neuroprotection. Trends Neurosci 2003; 26: 248-54.

[194] Gidday JM. Cerebral preconditioning and ischaemic tolerance. Nat Rev Neurosci 2006; 7: 437-48.

[195] Obrenovitch TP. Molecular physiology of preconditioning-induced brain tolerance to ischemia. Physiol Rev 2008; 88: 211-47.

[196] Cadet JL, Krasnova IN. Cellular and molecular neurobiology of brain preconditioning. Mol Neurobiol 2009; 39: 50-61.

[197] Dirnagl U, Meisel A. Endogenous neuroprotection: mitochondria as gateways to cerebral preconditioning? Neuropharmacology 2008; 55: 334-44.

[198] Yenari M, Kitagawa K, Lyden P, Perez-Pinzon M. Metabolic downregulation: a key to successful neuroprotection? Stroke 2008; 39: 2910-7.

[199] Trendelenburg G, Dirnagl U. Neuroprotective role of astrocytes in cerebral ischemia: focus on ischemic preconditioning. Glia 2005; 50: 307-20.

[200] Marsh BJ, Williams-Karnesky RL, Stenzel-Poore MP. Toll-like receptor signaling in endogenous neuroprotection and stroke. Neuroscience 2009;158: 1007-20.

[201] Karikó K, Weissman D, Welsh FA. Inhibition of toll-like receptor and cytokine signaling--a unifying theme in ischemic tolerance. $\mathrm{J}$ Cereb Blood Flow Metab 2004; 24: 1288-304.

[202] Marini AM, Jiang X, Wu X, et al. Preconditioning and neurotrophins: a model for brain adaptation to seizures, ischemia and other stressful stimuli. Amino Acids 2007; 32: 299-304.

[203] Reshef A, Sperling O, Zoref-Shani E. The adenosine-induced mechanism for the acquisition of ischemic tolerance in primary rat neuronal cultures. Pharmacol Ther 2000; 87: 151-9.

[204] Reshef A, Sperling O, Zoref-Shani E. Opening of K(ATP) channels is mandatory for acquisition of ischemic tolerance by adenosine. Neuroreport 2000; 11: 463-5. 
[205] Hiraide T, Katsura K, Muramatsu H, Asano G, Katayama Y. Adenosine receptor antagonists cancelled the ischemic tolerance phenomenon in gerbil. Brain Res 2001; 910: 94-8.

[206] Blondeau N, Plamondon H, Richelme C, Heurteaux C, Lazdunski M. K(ATP) channel openers, adenosine agonists and epileptic preconditioning are stress signals inducing hippocampal neuroprotection. Neuroscience 2000; 100: 465-74.

[207] Plamondon H, Blondeau N, Heurteaux C, Lazdunski M. Mutually protective actions of kainic acid epileptic preconditioning and sublethal global ischemia on hippocampal neuronal death: involvement of adenosine A1 receptors and K(ATP) channels. J Cereb Blood Flow Metab 1999; 19: 1296-308.

[208] Schock SC, Munyao N, Yakubchyk Y, et al. Cortical spreading depression releases ATP into the extracellular space and purinergic receptor activation contributes to the induction of ischemic tolerance. Brain Res 2007; 1168: 129-38.

[209] Lin JH, Lou N, Kang N, et al. A central role of connexin 43 in hypoxic preconditioning. J Neurosci 2008; 28: 681-95.

[210] Fiebich BL, Biber K, Gyufko K, Berger M, Bauer J, van Calker D. Adenosine A2b receptors mediate an increase in interleukin (IL)-6 mRNA and IL-6 protein synthesis in human astroglioma cells. J Neurochem 1996; 66: 1426-31.

[211] Fiebich BL, Akundi RS, Biber K, et al. IL-6 expression induced by adenosine A2b receptor stimulation in U373 MG cells depends on p38 mitogen activated kinase and protein kinase $\mathrm{C}$. Neurochem Int 2005; 46: 501-12.

[212] Biber K, Lubrich B, Fiebich BL, Boddeke HW, van Calker D. Interleukin-6 enhances expression of adenosine A1 receptor mRNA and signaling in cultured rat cortical astrocytes and brain slices. Neuropsychopharmacology 2001; 24: 86-96.

[213] Biber K, Pinto-Duarte A, Wittendorp MC, et al. Interleukin-6 upregulates neuronal adenosine A1 receptors: implications for neuromodulation and neuroprotection. Neuropsychopharmacology 2008; 33: 2237-50.

[214] Li T, Quan Lan J, Fredholm BB, Simon RP, Boison D. Adenosine dysfunction in astrogliosis: cause for seizure generation? Neuron Glia Biol 2007; 3: 353-66.

[215] Cunha RA. Neuroprotection by adenosine in the brain: From A1 receptor activation to A2A receptor blockade. Purinergic Signal 2005; 1 : 111-34

[216] Chen JF, Sonsalla PK, Pedata F, et al. Adenosine A2A receptors and brain injury: broad spectrum of neuroprotection, multifaceted actions and "fine tuning" modulation. Prog Neurobiol 2007; 83: 310-31.

[217] Lopes LV, Halldner L, Rebola N, et al. Binding of the prototypical adenosine A2A receptor agonist CGS 21680 to the cerebral cortex of adenosine $\mathrm{A} 1$ and $\mathrm{A} 2 \mathrm{~A}$ receptor knockout mice. $\mathrm{Br} \mathrm{J}$ Pharmacol 2004; 141: 1006-14.

[218] De Sarro G, De Sarro A, Di Paola ED, Bertorelli R. Effects of adenosine receptor agonists and antagonists on audiogenic seizuresensible DBA/2 mice. Eur J Pharmacol 1999; 371: 137-45.

[219] El Yacoubi M, Ledent C, Parmentier M, Daoust M, Costentin J, Vaugeois J. Absence of the adenosine A2A receptor or its chronic blockade decrease ethanol withdrawal-induced seizures in mice. Neuropharmacology 2001; 40: 424-32.

[220] Huber A, Güttinger M, Möhler H, Boison D. Seizure suppression by adenosine A2A receptor activation in a rat model of audiogenic brainstem epilepsy. Neurosci Lett 2002; 329: 289-92.

[221] Etherington LA, Frenguelli BG. Endogenous adenosine modulates epileptiform activity in rat hippocampus in a receptor subtypedependent manner. Eur J Neurosci 2004; 19: 2539-50.

[222] Zeraati M, Mirnajafi-Zadeh J, Fathollahi Y, Namvar S, Rezvani ME. Adenosine A1 and A2A receptors of hippocampal CA1 region have opposite effects on piriform cortex kindled seizures in rats. Seizure 2006; 15: 41-8.

[223] Hosseinmardi N, Mirnajafi-Zadeh J, Fathollahi Y, Shahabi P. The role of adenosine $\mathrm{A} 1$ and $\mathrm{A} 2 \mathrm{~A}$ receptors of entorhinal cortex on piriform cortex kindled seizures in rats. Pharmacol Res 2007; 56: 110-7.

[224] Rezvani ME, Mirnajafi-Zadeh J, Fathollahi Y, Palizvan MR. Anticonvulsant effect of A1 but not A2A adenosine receptors of piri- form cortex in amygdala-kindled rats. Can J Physiol Pharmacol 2007; 85: 606-12.

[225] D'Alimonte I, D'Auro M, Citraro R, et al. Altered distribution and function of A2A adenosine receptors in the brain of WAG/Rij rats with genetic absence epilepsy, before and after appearance of the disease. Eur J Neurosci 2009; 30: 1023-35.

[226] El Yacoubi M, Ledent C, Parmentier M, Costentin J, Vaugeois JM. Adenosine A2A receptor deficient mice are partially resistant to limbic seizures. Naunyn Schmiedebergs Arch Pharmacol 2009; 380: 223-32.

[227] El Yacoubi M, Ledent C, Parmentier M, Costentin J, Vaugeois JM. Evidence for the involvement of the adenosine A2A receptor in the lowered susceptibility to pentylenetetrazol-induced seizures produced in mice by long-term treatment with caffeine. Neuropharmacology 2008; 55: 35-40.

[228] Porciúncula LO, Canas PM, Oliveira CR, Cunha RA. Blockade of adenosine A2A receptors differently alters convulsive behaviour and prevents hippocampal damage in two models of temporal lobe epilepsy. Purinergic Signal 2006; 2: 134.

[229] Al Moutaery K, Al Deeb S, Ahmad Khan H, Tariq M. Caffeine impairs short-term neurological outcome after concussive head injury in rats. Neurosurgery 2003; 53: 704-11.

[230] Sachse KT, Jackson EK, Wisniewski SR, et al. Increases in cerebrospinal fluid caffeine concentration are associated with favorable outcome after severe traumatic brain injury in humans. J Cereb Blood Flow Metab 2008; 28: 395-401.

[231] Tebano MT, Martire A, Rebola N, et al. Adenosine A2A receptors and metabotropic glutamate 5 receptors are co-localized and functionally interact in the hippocampus: a possible key mechanism in the modulation of N-methyl-D-aspartate effects. J Neurochem 2005; 95: 1188-200.

[232] Azdad K, Gall D, Woods AS, Ledent C, Ferré S, Schiffmann SN. Dopamine D2 and adenosine A2A receptors regulate NMDAmediated excitation in accumbens neurons through A2A-D2 receptor heteromerization. Neuropsychopharmacology 2009; 34: 972-86.

[233] Stone TW, Behan WM. Interleukin-1beta but not tumor necrosis factor-alpha potentiates neuronal damage by quinolinic acid: protection by an adenosine A2A receptor antagonist. J Neurosci Res 2007; 85: 1077-85.

[234] Canas PM, Porciúncula LO, Cunha GM, et al. Adenosine A2A receptor blockade prevents synaptotoxicity and memory dysfunction caused by beta-amyloid peptides via p38 mitogen-activated protein kinase pathway. J Neurosci 2009; 29: 14741-51.

[235] Selkoe DJ, Schenk D. Alzheimer's disease: molecular understanding predicts amyloid-based therapeutics. Annu Rev Pharmacol Toxicol 2003; 43: 545-84.

[236] Cognato GP, Agostinho PM, Hockemeyer J, Müller CE, Souza DO, Cunha RA. Caffeine and an adenosine A2A receptor antagonist prevent memory impairment and synaptotoxicity in adult rats triggered by a convulsive episode in early life. J Neurochem 2009; 112: 453-62.

[237] Silva CG, Porciúncula LO, Canas PM, Oliveira CR, Cunha RA. Blockade of adenosine A2A receptors prevents staurosporineinduced apoptosis of rat hippocampal neurons. Neurobiol Dis 2007; 27: 182-9.

[238] Saura J, Angulo E, Ejarque A, et al. Adenosine A2A receptor stimulation potentiates nitric oxide release by activated microglia. J Neurochem 2005; 95: 919-29.

[239] Lee YC, Chien CL, Sun CN, et al. Characterization of the rat A2A adenosine receptor gene: a $4.8-\mathrm{kb}$ promoter-proximal DNA fragment confers selective expression in the central nervous system. Eur J Neurosci 2003; 18: 1786-96.

[240] Yu L, Shen HY, Coelho JE, et al. Adenosine A2A receptor antagonists exert motor and neuroprotective effects by distinct cellular mechanisms. Ann Neurol 2008; 63: 338-46.

[241] Pintor A, Galluzzo M, Grieco R, Pèzzola A, Reggio R, Popoli P. Adenosine A2A receptor antagonists prevent the increase in striatal glutamate levels induced by glutamate uptake inhibitors. J Neurochem 2004; 89: 152-6.

[242] Brambilla R, Cottini L, Fumagalli M, Ceruti S, Abbracchio MP. Blockade of $\mathrm{A} 2 \mathrm{~A}$ adenosine receptors prevents basic fibroblast 
growth factor-induced reactive astrogliosis in rat striatal primary astrocytes. Glia 2003; 43: 190-4.

[243] Flajolet M, Wang Z, Futter M, et al. FGF acts as a co-transmitter through adenosine $\mathrm{A} 2 \mathrm{~A}$ receptor to regulate synaptic plasticity. Nat Neurosci 2008; 11: 1402-9.

[244] Minghetti L, Greco A, Potenza RL, et al. Effects of the adenosine A2A receptor antagonist SCH 58621 on cyclooxygenase-2 expression, glial activation, and brain-derived neurotrophic factor availability in a rat model of striatal neurodegeneration. J Neuropathol Exp Neurol 2007; 66: 363-71.

[245] Heese K, Fiebich BL, Bauer J, Otten U. Nerve growth factor (NGF) expression in rat microglia is induced by adenosine A2areceptors. Neurosci Lett 1997; 231: 83-6.

[246] Duan W, Gui L, Zhou Z, et al. Adenosine A2A receptor deficiency exacerbates white matter lesions and cognitive deficits induced by chronic cerebral hypoperfusion in mice. J Neurol Sci 2009; 285 : $39-45$.

[247] van der Putten C, Zuiderwijk-Sick EA, van Straalen L, et al. Differential expression of adenosine A3 receptors controls adenosine A2A receptor-mediated inhibition of TLR responses in microglia. $\mathrm{J}$ Immunol 2009; 182: 7603-12.

[248] Melani A, Cipriani S, Vannucchi MG, et al. Selective adenosine A2a receptor antagonism reduces JNK activation in oligodendrocytes after cerebral ischaemia. Brain 2009; 132: 1480-95.

[249] Carta AR, Kachroo A, Schintu N, et al. Inactivation of neuronal forebrain $\mathrm{A} 2 \mathrm{~A}$ receptors protects dopaminergic neurons in a mouse model of Parkinson's disease. J Neurochem 2009; 111: 1478-89.

[250] Yu L, Huang Z, Mariani J, Wang Y, Moskowitz M, Chen JF. Selective inactivation or reconstitution of adenosine A2A receptors in bone marrow cells reveals their significant contribution to the development of ischemic brain injury. Nat Med 2004; 10: 1081-7.

[251] Chen X, Gawryluk JW, Wagener JF, Ghribi O, Geiger JD. Caffeine blocks disruption of blood brain barrier in a rabbit model of Alzheimer's disease. J Neuroinflammation 2008; 5: 12.

[252] Chen X, Lan X, Roche I, Liu R, Geiger JD. Caffeine protects against MPTP-induced blood-brain barrier dysfunction in mouse striatum. J Neurochem 2008; 107: 1147-57.

[253] O'Regan M. Adenosine and the regulation of cerebral blood flow. Neurol Res 2005; 27: 175-81.

[254] Ohata H, Cao S, Koehler RC. Contribution of adenosine A2A and A2B receptors and heme oxygenase to AMPA-induced dilation of pial arterioles in rats. Am J Physiol 2006; 291: R728-35.

[255] Phillis JW, Lungu CL, Barbu DE, O'Regan MH. Adenosine's role in hypercapnia-evoked cerebral vasodilation in the rat. Neurosci Lett 2004; 365: 6-9.

[256] Meno JR, Crum AV, Winn HR. Effect of adenosine receptor blockade on pial arteriolar dilation during sciatic nerve stimulation. Am J Physiol 2001; 281: H2018-27.

[257] Ngai AC, Coyne EF, Meno JR, West GA, Winn HR. Receptor subtypes mediating adenosine-induced dilation of cerebral arterioles. Am J Physiol 2001; 280: H2329-35.

[258] Kusano Y, Echeverry G, Miekisiak G, et al. Role of adenosine A2 receptors in regulation of cerebral blood flow during induced hypotension. J Cereb Blood Flow Metab 2010; 30: 808-15.

[259] Nagy AK, Houser CR, Delgado-Escueta AV. Synaptosomal ATPase activities in temporal cortex and hippocampal formation of humans with focal epilepsy. Brain Res 1990; 529: 192-201.

[260] Nagy AK, Walton NY, Treiman DM. Reduced cortical ectoATPase activity in rat brains during prolonged status epilepticus induced by sequential administration of lithium and pilocarpine. Mol Chem Neuropathol 1997; 31: 135-47.

[261] Bonan CD, Walz R, Pereira GS, et al. Changes in synaptosomal ectonucleotidase activities in two rat models of temporal lobe epilepsy. Epilepsy Res 2000; 39: 229-38.

[262] de Paula Cognato G, Bruno AN, Vuaden FC, Sarkis JJ, Bonan CD. Ontogenetic profile of ectonucleotidase activities from brain synaptosomes of pilocarpine-treated rats. Int J Dev Neurosci 2005; 23: 703-9.

[263] Schoen SW, Ebert U, Löscher W. 5'-Nucleotidase activity of mossy fibers in the dentate gyrus of normal and epileptic rats. Neuroscience $1999 ;$ 93: 519-26.
[264] Lie AA, Blümcke I, Beck H, Wiestler OD, Elger CE, Schoen SW 5'-Nucleotidase activity indicates sites of synaptic plasticity and reactive synaptogenesis in the human brain. J Neuropathol Exp Neurol 1999; 58: 451-8.

[265] James S, Richardson PJ. Production of adenosine from extracellular ATP at the striatal cholinergic synapse. J Neurochem 1993; 60: 219-27.

[266] Burnstock G. Physiology and pathophysiology of purinergic neurotransmission. Physiol Rev 2007; 87: 659-797.

[267] Edwards FA, Gibb AJ, Colquhoun D. ATP receptor-mediated synaptic currents in the central nervous system. Nature 1992; 359: 144-7.

[268] Robertson SJ, Ennion SJ, Evans RJ, Edwards FA. Synaptic P2X receptors. Curr Opin Neurobiol 2001; 11: 378-86.

[269] Cunha RA, Ribeiro JA. ATP as a presynaptic modulator. Life Sci 2000; 68: 119-37.

[270] Sperlágh B, Heinrich A, Csölle C. P2 receptor-mediated modulation of neurotransmitter release-an update. Purinergic Signal 2007; 3: $269-84$.

[271] Inoue K, Koizumi S, Tsuda M. The role of nucleotides in the neuron--glia communication responsible for the brain functions. J Neurochem 2007; 102: 1447-58.

[272] Fields RD, Burnstock G. Purinergic signalling in neuron-glia interactions. Nat Rev Neurosci 2006; 7: 423-36.

[273] Arcuino G, Lin JH, Takano T, et al. Intercellular calcium signaling mediated by point-source burst release of ATP. Proc Natl Acad Sci USA 2002; 99: 9840-5.

[274] Abbracchio MP, Verderio C. Pathophysiological roles of P2 receptors in glial cells. Novartis Found Symp 2006; 276: 91-103.

[275] Ferrari D, Pizzirani C, Adinolfi E, et al. The P2X7 receptor: a key player in IL-1 processing and release. J Immunol 2006; 176: 3877 83.

[276] Färber K, Kettenmann H. Purinergic signaling and microglia. Pflugers Arch 2006; 452: 615-21.

[277] Rathbone MP, Middlemiss PJ, Gysbers JW, et al. Trophic effects of purines in neurons and glial cells. Prog Neurobiol 1999; 59: 663 90 .

[278] Agresti C, Meomartini ME, Amadio S, et al. ATP regulates oligodendrocyte progenitor migration, proliferation, and differentiation: involvement of metabotropic P2 receptors. Brain Res Rev 2005; 48: 157-65.

[279] Lin JH, Takano T, Arcuino G, et al. Purinergic signaling regulates neural progenitor cell expansion and neurogenesis. Dev Biol 2007; 302: 356-66.

[280] Liu X, Hashimoto-Torii K, Torii M, Haydar TF, Rakic P. The role of ATP signaling in the migration of intermediate neuronal progenitors to the neocortical subventricular zone. Proc Natl Acad Sci USA 2008; 105: 11802-7.

[281] Franke H, Krügel U, Illes P. P2 receptors and neuronal injury. Pflugers Arch 2006; 452: 622-44.

[282] Abbracchio MP, Burnstock G, Verkhratsky A, Zimmermann H. Purinergic signalling in the nervous system: an overview. Trends Neurosci 2009; 32: 19-29.

[283] Di Virgilio F. Dr. Jekyll/Mr. Hyde: the dual role of extracellular ATP. J Auton Nerv Syst 2000; 81: 59-63.

[284] Wang X, Arcuino G, Takano T, et al. P2X7 receptor inhibition improves recovery after spinal cord injury. Nat Med 2004; 10: 8217.

[285] Davalos D, Grutzendler J, Yang G, et al. ATP mediates rapid microglial response to local brain injury in vivo. Nat Neurosci 2005 8: 752-8.

[286] Melani A, Turchi D, Vannucchi MG, Cipriani S, Gianfriddo M, Pedata F. ATP extracellular concentrations are increased in the rat striatum during in vivo ischemia. Neurochem Int 2005; 47: 442-8.

[287] Peng W, Cotrina ML, Han X, et al, Nedergaard M. Systemic administration of an antagonist of the ATP-sensitive receptor P2X7 improves recovery after spinal cord injury. Proc Natl Acad Sci USA 2009; 106: 12489-93.

[288] Lämmer A, Günther A, Beck A, et al. Neuroprotective effects of the $\mathrm{P} 2$ receptor antagonist PPADS on focal cerebral ischaemiainduced injury in rats. Eur J Neurosci 2006; 23: 2824-8. 
[289] Melani A, Amadio S, Gianfriddo M, et al. P2X7 receptor modulation on microglial cells and reduction of brain infarct caused by middle cerebral artery occlusion in rat. J Cereb Blood Flow Metab 2006; 26: 974-82.

[290] Vianna EP, Ferreira AT, Naffah-Mazzacoratti MG, et al. Evidence that ATP participates in the pathophysiology of pilocarpineinduced temporal lobe epilepsy: fluorimetric, immunohistochemical, and Western blot studies. Epilepsia 2002; 43(Suppl 5): 227-9.

[291] Wieraszko A, Seyfried TN. Increased amount of extracellular ATP in stimulated hippocampal slices of seizure prone mice. Neurosci Lett 1989; 106: 287-93.

[292] Doná F, Ulrich H, Persike DS, et al. Alteration of purinergic P2X4 and $\mathrm{P} 2 \mathrm{X} 7$ receptor expression in rats with temporal-lobe epilepsy induced by pilocarpine. Epilepsy Res 2009; 83: 157-67.

[293] Oses JP, Simões AP, Canas PM, et al. Modification by kainateinduced convulsions of the density of presynaptic $\mathrm{P} 2 \mathrm{X}$ receptors in the rat hippocampus. Purinergic Signal 2006; 2: 252.

[294] Avignone E, Ulmann L, Levavasseur F, Rassendren F, Audinat E. Status epilepticus induces a particular microglial activation state characterized by enhanced purinergic signaling. J Neurosci 2008; 28: 9133-44.

[295] Kumaria A, Tolias CM, Burnstock G. ATP signalling in epilepsy. Purinergic Signal 2008; 4: 339-46.
[296] Pankratov YV, Lalo UV, Krishtal OA. Role for P2X receptors in long-term potentiation. J Neurosci 2002; 22: 8363-9.

[297] Almeida T, Rodrigues RJ, de Mendonça A, Ribeiro JA, Cunha RA. Purinergic $\mathrm{P} 2$ receptors trigger adenosine release leading to adenosine A2A receptor activation and facilitation of long-term potentiation in rat hippocampal slices. Neuroscience 2003; 122: 111-21.

[298] Yamazaki Y, Kaneko K, Fujii S, Kato H, Ito K. Long-term potentiation and long-term depression induced by local application of ATP to hippocampal CA1 neurons of the guinea pig. Hippocampus 2003; 13: 81-92.

[299] Wang Y, Haughey NJ, Mattson MP, Furukawa K. Dual effects of ATP on rat hippocampal synaptic plasticity. Neuroreport 2004; 15 : 633-6.

[300] Sim JA, Chaumont S, Jo J, et al. Altered hippocampal synaptic potentiation in P2X4 knock-out mice. J Neurosci 2006; 26: 9006-9.

[301] Knutsen LJS, Murray TF. Adenosine and ATP in epilepsy. In: Jacobson KA, Jarvis MF, Eds. Purinergic approaches in experimental therapeutics. Wiley-Liss: New York 1997; pp. 423-47.

[302] Dulla CG, Dobelis P, Pearson T, Frenguelli BG, Staley KJ, Masino SA. Adenosine and ATP link PCO2 to cortical excitability via $\mathrm{pH}$. Neuron 2005; 48: 1011-23.

Received: December 30, 2009

Revised: February 16, 2010

Accepted: March 22, 2010

(C) Tomé et al.; Licensee Bentham Open.

This is an open access article licensed under the terms of the Creative Commons Attribution Non-Commercial License (http://creativecommons.org/licenses/by-nc/3.0/) which permits unrestricted, non-commercial use, distribution and reproduction in any medium, provided the work is properly cited. 